\title{
Rwandan Refugee Physical (In) Security in Uganda: Views from Below
}

\author{
Ahimbisibwe Frank ${ }^{1,2,3}$ \\ ${ }^{1}$ Department of Planning and Governance, Mbarara University of Science and Technology, Uganda \\ ${ }^{2}$ Department of Development Studies, Kampala International University, Western Campus, Uganda \\ ${ }^{3}$ Institute of Development Policy, University of Antwerp, Belgium \\ Correspondence: Dr. Ahimbisibwe Frank, Department of Planning and Governance, Faculty of Interdisciplinary \\ Studies, Mbarara University of Science and Technology, Mbarara, Uganda. E-mail: fahimbisibwe@must.ac.ug; \\ fahimbisibwe@gmail.com
}

Received: January 19, 2019

Accepted: August 26, $2020 \quad$ Online Published: November 27, 2020

doi:10.5539/jpl.v14n1p50

URL: https://doi.org/10.5539/jpl.v14n1p50

The author acknowledges the financial support of VLIR-UOS Project, Ref. No ZEIN 2014 Z 171 and of the Institute of Development Policy and Management (IOB), University of Antwerp for his stay in Belgium (September 2016February 2017). I would like to thank Prof. Filip Reyntjens for his guidance and insightful comments. The usual disclaimer applies. This paper has been published before as a working paper under the details: Ahimbisibwe Frank (2017), "Rwandan Refugee Physical (In) Security in Uganda: Views from Below", Institute of Development Policy and Management (IOB), University of Antwerp, Working Paper No. 2017.03, ISSN 2294-8643.

\begin{abstract}
The paper analyzes the challenge of physical (in) security of Rwandan refugees in Nakivale and Oruchinga settlements, South Western Uganda. The paper is largely based on the views of the refugees themselves. It argues that contrary to her international obligations and the general view that Uganda is a hospitable asylum country, refugees face insecurity caused by a number of factors, including actions by their country of origin and the host state, as well as local settlement dynamics and internal sources. This insecurity has negatively affected the refugees, who have adopted a number of protection measures which supplement the ones put in place by the government and UNHCR. Despite the implementation of different security measures, insecurity still prevails in the settlements.
\end{abstract}

Keywords: Rwandan refugees, physical security, Nakivale, Oruchinga, Uganda, Rwanda

\section{Introduction}

According to UNHCR, "by the end of 2019, 79.5 million individuals were forcibly displaced as a result of persecution, conflict, violence, human rights violations or events seriously disturbing public order". ${ }^{1}$ Out of 79.5 million, 26 million were refugees ${ }^{2}, 45.7$ million Internally Displaced Persons and 4.2 million asylum seekers. ${ }^{3}$ Developing regions hosted 85 percent of the world's refugees under UNHCR mandate. ${ }^{4}$ Uganda was the $4^{\text {th }}$ and $1^{\text {st }}$ top refugee hosting country in the world and Africa respectively. It hosted over 1.4 million refugees. ${ }^{5}$ The majority of these refugees come from neighboring countries and the wider region, South Sudan, Democratic Republic of Congo, Burundi, Somalia, Rwanda, Kenya, Ethiopia and Eritrea among others. By June 2020 around

\footnotetext{
${ }^{1}$ UNHCR (2020), Global Trends: Forced Displacement in 2019, Geneva, UNHCR: 2, available at https://www.unhcr.org/globaltrends2019/ [accessed on 20 June 2020].

${ }^{2}$ Out of 26 million refugees, 20.4 million refugees are under UNHCR mandate and 5.6 million are Palestinian refugees registered by United Nations Relief and Works Agency.

${ }^{3}$ UNHCR "Global Trends", op.cit.

${ }^{4}$ Ibid.

${ }^{5}$ Ibid.
} 
17,483 of these were Rwandan ${ }^{6}$ who arrived during and after the 1994 Rwandan genocide.

Uganda as the host state has the obligation of providing physical security and safety to refugees fleeing persecution. Alupo reminds us that persons flee their country and seek protection as refugees in order to survive in safety and dignity. The immediate objective of international protection of refugees is therefore to ensure their physical safety and security. ${ }^{7}$ The cornerstone of the international system of refugee protection is the 1951 U.N. Convention relating to the status of Refugees, and its 1967 protocol. ${ }^{8}$ The protection of refugees under these instruments is supplemented by various regional agreements, including the 1969 Organization of African Unity (OAU) Convention Governing the Specific Aspects of Refugee Problems in Africa and a wider body of human rights and humanitarian law. ${ }^{9}$ The OAU Convention provides protection to refugees fleeing persecution, but also to those forced to flee due to serious disturbances of the public order in their countries of nationality. ${ }^{10} \mathrm{At}$ the domestic level, refugees are protected by the 2006 Refugees Act, ${ }^{11}$ the national law that guides Uganda's refugee protection.

Physical security is rooted in the concept of human security which emerged in the 1994 United Nations Development Programme (UNDP) Human Development Report ${ }^{12}$ as a way of expanding the concept of security. ${ }^{13}$ Physical security means personal security and it is concerned with protection of refugees' physical safety, dignity, lives and anything that may harm their bodies and physical wellbeing. It involves protection of refugees from threats like murder, torture, criminal attacks, conflict, domestic violence, sexual violence, suicide, drug abuse, hunger and all that endangers their physical existence. ${ }^{14}$ In fact "a person's perception of the risks they face is what determines whether or not they feel secure"15 and make the decision either to flee or stay.

This paper analyzes the physical (in) security of Rwandan new caseload refugees ${ }^{16}$ in Nakivale and Oruchinga settlements, south western Uganda based to a great extent on the views of refugees. It argues that contrary to a general view that Uganda is a hospitable asylum country, refugees face insecurity caused by a number of factors, including actions by their country of origin and the host state, as well as local settlement dynamics. This insecurity has negatively affected the refugees. The refugees have adopted a number of protection measures which supplement the ones put in place by the government and UNHCR. Despite the implementation of these security measures, insecurity still prevails in the settlements.

Although there has been sufficient scholarly attention to refugee security and protection ${ }^{17}$, there is little scholarly

6 Office of the Prime Minister \& UNHCR (2020), Uganda Comprehensive Refugee Response Portal, available at http://ugandarefugees.org/en/country/uga/[accessed on $30^{\text {th }}$ June 2020]. This number reduced from 25,000 in 2003 when the tripartite agreement of voluntary repatriation was signed.

${ }^{7}$ Alupo, Susan (2009), State Responsibility for the Rights of Refugees: A Critical Analysis on the Security of Refugees in Uganda, Master Thesis, Unpublished, Oslo, University of Oslo: 7.

${ }^{8}$ Brenda, Bowser Soder (2011), "States' Obligations to Protect Refugees Fleeing Libya: Backgrounder", March 1, available on line: http://www.humanrightsfirst.org/2011/03/01/states-obligations-to-protect-refugees-fleeing-libya-backgrounder/, [accessed on October $15^{\text {th }}$ 2011].

${ }^{9}$ Ibid.

${ }^{10}$ Ibid.

${ }^{11}$ Rights are spelt out in Part V - "Rights and Obligations of Refugees", Sections 28 to 36 of the Uganda 2006 Refugees Act.

12 The report discusses new dimensions of human security as economic security, food security, health security, environmental security, personal security, community security and political security. This new conceptualization of security is relevant to refugee protection. Refugee security is all about fulfilling and protecting human security of refugees and its components. One element of human security according to the 1994 UNDP report is relevant to this paper that is personal security that is concerned with physical safety (physical security).

${ }^{13}$ For more discussion on the conceptualization of security and human security, See United Nations Development Programme (1994), Human Development Report; Canadian, Norwegian and Japanese Ministries of Foreign Affairs; South African White Paper on Defense, 1996 and Ugandan White Paper on Defense, 2002; Keith Krause \& Michael C. Williams (eds) (1997), Critical Security Studies, Minneapolis: University of Minnesota Press; Barry Buzan (1991), People, States and Fear: An Agenda for International Security Studies in the Post-Cold War Era, $2^{\text {nd }}$ Ed, New York: Harvester Wheatsheaf; Paris Roland (2001), “Human Security: Paradigm Shift or Hot Air?” International Security 26 (2): 87 102; Baldwin, D.A, (1997), “The Concept of Security”, Review of International Studies 23(1), 5-26.

${ }^{14}$ UNHCR (2006), “Addressing Refugee Security” in The State of the World's Refugees: Human Displacement in the New Millennium, Oxford \& New York, Oxford University Press, $20^{\text {th }}$ April, available athttp://www.unhcr.org/4a4dc1a89.html [accessed on 24 $4^{\text {th }}$ October 2013].

15 ODI/HPG (2004), "Humanitarian Protection and Politics of Influence: A Study of Concepts and Practice in the Protection of Civilians", Discussion Paper, $25^{\text {th }}$ June.

${ }^{16}$ Rwandan new caseload refugees refer to Hutu that came during and after the 1994 genocide. Before them, Uganda hosted old case load Rwandan Tutsi refugees who arrived in 1959 and the early 1960s. The majority returned to Rwanda after the genocide while a significant number stayed in Uganda.

${ }^{17}$ Crisp Jeff (2000), "Forms and Sources of Violence in Kenya's Refugee Camps", Refugee Survey Quarterly, Vol. 19, No.1: 69; Milner, James (2000), "Sharing the Security Burden: Towards the Convergence of Refugee Protection and State Security", Refugee Studies Centre 
writing focused on the views and perspectives of stakeholders especially the refugees. This paper is different from others because it lets the refugees speak and their claims and perspectives are verified by the external points of view of stakeholders.

This article is based on three research visits carried out at different intervals in Nakivale and Oruchinga settlements in south western Uganda. The first visit took place between June 2010 and December 2011. A second visit took place between June and August 2016. The third visit was carried out from 26th to 31st January 2018. The study focused on Rwandan new caseload refugees that came to Uganda after 1994 and used a qualitative research methodology. Semi-structured and key informant interviews, Focus Group Discussions (FGDs), observation and documentary evidence were the main research techniques. Purposive criterion sampling was used to select the study respondents, namely Rwandan refugees, Rwandan and Ugandan government officials, UNHCR and NGOs officials, as well as local hosts around Nakivale and Oruchinga settlements, Isingiro District. ${ }^{18}$ In addition, 'recyclers' ${ }^{19}$ were identified through snowball sampling. Rwandan refugees and other categories of respondents answered questions on themes like refugee physical security, refugee rights and obligations, voluntary and forced repatriation, local integration, resettlement, the so-called cessation clause and, in general, avenues to find durable solutions. ${ }^{20}$ The analysis further makes use of secondary data, both scholarly articles and grey literature.

The paper is structured as follows. The first section addresses the views of Rwandan refugees verified by the external points of view of stakeholders on the causes of insecurity. Subsequently, the paper analyzes the effects of insecurity and the measures adopted by refugees to improve security. Based on this analysis, the paper concludes with methodological and policy implications.

\section{Causes and Forms of Insecurity}

This section explores the causes, forms and dynamics of Rwandan refugee physical (in) security in Nakivale and Oruchinga settlements in South-western Uganda. This insecurity is categorized under the following: the country of origin, host state, local settlements dynamics and internal sources.

\subsection{Country of Origin}

\subsubsection{Rwandan Security Operations}

Actions undertaken by Rwanda are among the main causes of insecurity. The refugees even claimed that their country of origin is responsible for their misery and insecurity. Actions of its security operatives feature prominently in their concerns. The settlements are accessible to Rwandan agents who come to Uganda to spy on or kidnap refugees. Insecurity is heightened by the closeness of the settlements to Rwanda (Nakivale and Oruchinga are approximately 70 and 52 kilometers respectively from the border $)^{21}$. A refugee man noted that "Nakivale is just like a part of Rwanda... the Rwandan authorities know exactly what is taking place here in Nakivale. Nakivale is near Rwanda and is easily accessible by Rwandan security officials". ${ }^{22}$ A refugee woman expressed her fear that Oruchinga is very close to the Rwandan border. She noted that the settlement is in the

\footnotetext{
Working Paper No. 4, University of Oxford, May; Crisp Jeff (2000), “A State of Insecurity: The Political Economy of Violence in Kenya's Refugee Camps", African Affairs, Vol. 99:601-632.

${ }_{18}$ The first visit involved 162 respondents. 1 FGD, each with 12 Rwandans was organized in each of the 3 zones in Nakivale; Base Camp, Juru and Rubondo. In each of the zones, I interviewed 10 refugee leaders. I also interviewed 10 recyclers, 10 Isingiro district officials, 11 Officials from Office of the Prime Minister (OPM), 16 NGOs staff, 10 police officers, 36 local hosts (6 locals from each of the 6 sub-counties bordering Nakivale), 1 expert on refugee studies and 2 officials from the Rwandan High Commission in Kampala. In the second visit, a total of 182 respondents participated in the study. 4 FGDs each with 10 Rwandan refugees were organized in 4 zones of Nakivale settlement; Base Camp, Juru, Rubondo and Kabazana. The $5^{\text {th }}$ FGD with 10 Rwandan refugees was organized in Oruchinga settlement. I interviewed 10 refugee leaders from each of the 4 zones in Nakivale. 10 refugee leaders were interviewed in Oruchinga settlement. Apart from the refugees, I interviewed 16 recyclers (10 in Nakivale and 6 in Oruchinga), 10 new asylum seekers (6 in Nakivale and 4 in Oruchinga), 6 OPM officials (4 in Nakivale and 2 in Oruchinga), 4 Isingiro district officials, 34 local hosts (24 in Nakivale and 10 in Oruchinga), 10 NGOs staff (6 in Nakivale and 4 in Oruchinga) and 2 officials from the Rwandan High Commission in Kampala. In the third visit, a total of 48 respondents participated. In Nakivale settlement, 24 Rwandan refugees, 4 recyclers and 2 OPM officials were interviewed. In Oruchinga, I interviewed 14 Rwandan refugees, 2 recyclers and 2 OPM officials.

19 Recyclers are refugees who were repatriated to Rwanda but later returned to Uganda claiming human rights violations, insecurity, persecution and inability to recover land and property in Rwanda.

${ }^{20}$ The study observed ethical principles in research. The study was cleared by the Office of the Prime Minister and Isingiro District in Uganda. During the data collection exercise, the respondents were briefed on the purpose of the study which was purely academic. Their confidentiality, informed consent and voluntary participation were observed and respected.

${ }^{21}$ According to the 1969 OAU Convention, "for reasons of security, countries of asylum shall, as far as possible, settle refugees at a reasonable distance from the frontier of their country of origin". Although the concept of 'reasonable distance' has never been officially defined, UNHCR and state practice puts it at 50 kilometers.

22 Interview with a refugee man, Juru zone, Nakivale Settlement on $24^{\text {th }}$ June 2010.
} 
backyard of Rwanda. ${ }^{23}$ A refugee man added that "Nakivale is like a territory of Rwanda. President Kagame knows exactly what happens here. He knows those who have money, how many children per family and those who are politically active. His main aim is to kill those who are rich and politically active. He considers them a threat to his regime". ${ }^{24}$ Another interviewee said: "There is an example of a Rwandan refugee who was abducted here in Nakivale settlement and put in a car by unknown people. Fortunately, the person was rescued by the Ugandan police near Kabingo town. We later learnt that our colleague had been abducted by Rwandan agents who wanted to take him to Kigali". ${ }^{25}$ In a FGD, refugees expressed fear spying and possible abduction by the Rwandan agents. They also mentioned colleagues who were abducted in Oruchinga settlement. ${ }^{26}$

These facts were confirmed by the Ugandan security officials who acknowledged that there was frequent spying on the refugees from Rwandan officials seeking intelligence on suspected genocide perpetrators or refugees involved in armed rebellion against Rwanda. ${ }^{27}$ An OPM official noted: "There is a time when we arrested Rwandan agents in Nakivale and we asked them to leave. It is common knowledge that Rwandan spies operate in settlements". ${ }^{28}$

Various stakeholders from OPM, UNHCR and NGOs noted that the Rwandan government has genuine reasons for closely monitoring refugees in Uganda because it knows their potential as a security threat. One of the officials noted that "President Kagame was here in Uganda as a refugee. The struggle to liberate Rwanda started here in Nakivale. He knows very well these refugees can be mobilized by people opposed to his government. He has interest in returning all refugees to avoid future insecurity". ${ }^{29}$

Harrell-Bond notes that the Rwandan Patriotic Front (RPF), in collaboration with Ugandan military and police, has been engaged in abductions of any Rwandan suspected of collaborating with the Hutu militia, the Interahamwe. ${ }^{30}$ For example, the Ugandan Human Rights Commission publically condemned the External Security Organization (ESO) and Internal Security Organization (ISO) for collaborating with Rwandan intelligence services to abduct Rwandan Hutu refugees. ${ }^{31}$ Human Rights Watch has also reported on the harassment of refugees by Rwandan agents. ${ }^{32}$

Amnesty International also raised this issue and called "attention to these same cases of abduction and deportation, arbitrary arrest and extra-judicial execution of Rwandan nationals within Uganda". ${ }^{33}$ Today, these abductions and executions of Rwandan refugees continue to be reported by Ugandan newspapers. ${ }^{34}$ Other sources have documented the abduction and murder of Rwandan refugees. ${ }^{35}$

\subsubsection{Forced Repatriation and Cessation Clause}

The post-genocide regime in Rwanda has aggressively promoted the repatriation of Rwandan refugees from other countries. It has pushed UNHCR and host countries that refugees no longer have any justification for refugee status. Rwanda has made the return of refugees one of its top foreign policy objectives. The neighbors including

\footnotetext{
${ }^{23}$ Interview with a refugee woman, Oruchinga settlement on $29^{\text {th }}$ August 2016.

${ }^{24}$ Interview with a refugee man, Kigali village, Nakivale Settlement on $16^{\text {th }}$ June 2016.

${ }^{25}$ Interview with a refugee man, Rubondo zone, Nakivale Settlement on $7^{\text {th }}$ July 2010.

${ }^{26}$ Focus Group Discussion, Oruchinga settlement on $29^{\text {th }}$ August 2016.

${ }^{27}$ Interview with a Police officer, Kashojwa police post, Nakivale Settlement on $29^{\text {th }}$ June 2016; Interview with a police officer, Kabahinda police post, Nakivale settlement on $20^{\text {th }}$ June 2016.

${ }^{28}$ Interview with Assistant Settlement Commandant, Rubondo zone, Nakivale settlement on $29^{\text {th }}$ July 2010.

${ }^{29}$ Interview with Refugee Desk Officer, Office of the Prime Minister, Mbarara on 27 $7^{\text {th }}$ August 2016; Interview with Deputy Commandant, Nakivale settlement on $28^{\text {th }}$ January 2018.

${ }^{30}$ See Harrell-Bond Barbara (2011), Cessation Clause Uganda Style, Keynote Speech Delivered at the Northwestern University Conference on Human Rights, January 23, Working Paper 11-001, January.

${ }^{31}$ Ibid.

${ }^{32}$ Human Rights Watch (2002), Hidden in Plain View: Refugees Living Without Protection in Nairobi and Kampala, New York: Human Rights Watch Publications.

${ }^{33}$ Amnesty International (2004), Rwanda: The Enduring Legacy of Genocide and War, $5^{\text {th }}$ April.

${ }^{34}$ Musisi Frederic \& Kasasira Risdel (2014), "Police Foil Kidnap of Another Rwandan Refugee", Daily Monitor, Saturday April 122014, available at http://www.monitor.co.ug/News/National/Police-foil-kidnap-of-another-Rwandan-refugee/-/688334/2275862/-/15gcw6uz//index.html [accessed on 12th April 2014]; Mujuni Raymond (2014), Rwanda Denies Kidnapping Refugee in Uganda, New Vision, April 16 ${ }^{\text {th }}$ 2014, available at http://www.newvision.co.ug/news/654615-rwanda-denies-kidnapping-refugee-in-uganda.html [accessed on 17th April 2014].

${ }^{35}$ See Amahoro People's Congress, Rwanda National Congress \& FDU-Inkingi (2013), Open Letter to the President on the Treatment of Rwandan Asylum Seekers and Refugees Living in Uganda, $7^{\text {th }}$ November, available at http://www.fdu-rwanda.com/wpcontent/uploads/2013/11/Letter-to-President-Museveni-on-Rwandan-refugees.pdf, [accessed on $15^{\text {th }}$ January 2014].
} 
Uganda are pressurized into supporting this objective.

One respondent claimed that "Kagame has been pushing hard for our forced return. He is on record to have said that Rwandan refugees in Nakivale will have to return home just like we did in Tanzania, DRC and Burundi". ${ }^{36}$ Another refugee woman said: "Kagame said on national television and radio that he will not rest until all the refugees in Nakivale have returned home. He asked why we are not returning. To him our continued stay in exile meant that we are running away from justice and reconciliation". ${ }^{37}$ In a Focus Group Discussion, refugees noted: "Rwanda is behind the pending cessation clause. It has deceived other countries that we no longer have any reason to remain refugees. These are lies and should not be accepted. We have well-founded fear of persecution". ${ }^{38}$

The above views are supported by other sources. According to International Refugee Rights Initiative, Refugee Law Project \& Social Science Research Council, “..... The Rwandan government itself has aggressively promoted the return of all its citizens because of security fears and a concern for the country's public image". ${ }^{39}$

A Senior Protection Officer in the Office of the Prime Minister noted that: "Our colleagues from Rwanda have been pushing us in tripartite commission meetings to accept their point of view of declaring cessation clause and forced repatriation of Rwandan refugees. At times we don't agree with them but we are forced to compromise on our positions and policy because of the need to maintain good interstate diplomatic relations". ${ }^{40} \mathrm{This}$ was confirmed by a Refugee Law Project official: "Obviously Rwanda is strongly pushing other countries to force all Rwandan refugees to return. Kagame knows the implications of not repatriating refugees outside Rwandan territory. Remember there is an active rebel group opposed to the Kigali government. Who knows Rwandan refugees in Uganda are a recruiting ground for these rebels. Because of national security interests, Kagame has made refugee repatriation one of his foreign policy priorities". ${ }^{41}$

\subsubsection{Ban on Cultivation}

The refugees noted that the policy on ban on cultivation is externally influenced by the Rwandan government. They observed that in a bid to strongly promote repatriation of its nationals, Rwanda has influenced Uganda to ban cultivation and reduce food rations for Rwandan refugees. A refugee woman noted: "Even if they stop us from cultivating, we will not return to Rwanda. Our refusal to return home is not connected to land in Nakivale. We would have returned immediately government stopped cultivation activities. Our failure to return is closely related to politics, human rights and justice in Rwanda". ${ }^{42}$ In a FGD, refugees argued that: "We know Kagame is trying to force Uganda to expel us. We know Uganda has no problem with us. We have been living here without harassment from the government. Uganda has always allowed us to cultivate until 2009 when we were stopped. We request OPM to allow us cultivate". ${ }^{43}$

Officials from OPM and NGOs agreed that Rwanda had influenced the policy to ban cultivation for refugees. According to an OPM official: "There was a belief that Rwandan refugees were not willing to return because of access to land in Nakivale. Rwandans were the most productive cultivating mainly maize and beans. Our Rwandan colleagues thought that by denying refugees land, they would be encouraged to return. They asked us to stop cultivation as a way of encouraging repatriation". ${ }^{44}$ Another respondent said: "Rwanda at first thought that refugees were not returning due to land access in Nakivale. This issue of land was raised in the Tripartite Repatriation Commission and an agreement reached to stop Rwandan refugees' access to land. They thought this would encourage repatriation. However, this policy has backfired since there are no refugees voluntarily registering for

\footnotetext{
${ }^{36}$ Interview with a refugee woman, Juru zone, Nakivale settlement on $24^{\text {th }}$ June 2010; Interview with a refugee man, Sangano, Nakivale settlement on $27^{\text {th }}$ January 2018 .

${ }^{37}$ Interview with a refugee woman, Sangano, Nakivale settlement on $23^{\text {rd June }} 2016$.

${ }^{38}$ Focus Group Discussion, Oruchinga settlement on $29^{\text {th }}$ August 2016; Interview with a refugee man, Oruchinga settlement on $26^{\text {th }}$ January 2018.

39 International Refugee Rights Initiative, Refugee Law Project \& Social Science Research Council (2010), A Dangerous Impasse: Rwandan Refugees in Uganda,9 June:8, available at: http://refugeelawproject.org/others/10_06_28_A_Dangerous_Impasse,Rwandan_Refugees_in_Uganda.pdf [accessed on 15 November 2016].

${ }^{40}$ Interview with Senior Protection Officer, Office of the Prime Minister, Kampala on $16^{\text {th }}$ August 2010; Interview with a Protection officer, Office of the Prime Minister, Kampala on $1^{\text {st }}$ June 2016.

${ }^{41}$ Interview with a Refugee Law Project official, Kampala on $15^{\text {th }}$ August 2010; Interview with a Refugee Law Project official, Mbarara on $10^{\text {th }}$ August 2016.

42 Interview with a refugee woman, Juru zone, Nakivale Settlement on $14^{\text {th }}$ July 2016; Interview with a refugee man, Juru zone, Nakivale settlement on $29^{\text {th }}$ January 2018.

${ }^{43}$ Focus Group Discussion, Rubondo zone, Nakivale Settlement on $8^{\text {th }}$ July 2010.

${ }^{44}$ Interview with Refugee Desk Officer, Office of the Prime Minister (OPM), Mbarara on 22 $2^{\text {nd }}$ July 2010; Interview with Office of the Prime Minister official, Mbarara on $10^{\text {th }}$ June 2016.
} 
repatriation". 45

According to the Settlement Commandant, Rwandan refugees were relying on food assistance from humanitarian agencies like the World Food Programme. ${ }^{46}$ Despite the ban on cultivation, the majority of Rwandan refugees were not willing to return. Thus, "we thought a good number would have returned by now but no one is interested in leaving Nakivale". ${ }^{4}$

\subsubsection{Events inside Rwanda}

Events inside Rwanda were a source of insecurity to the refugees. A significant number preferred to be in their home country but feared ethnic tensions, state persecution and imprisonment. Refugees lamented: "When we hear what is going on in Rwanda, we fear for our lives. Government officials close to Kagame are running away into exile. Kayumba Nyamwasa and many others have fallen out with the government. If top government officials can run away, what about us the ordinary people...?" ${ }^{48}$ In another FGD, refugees noted that: "We feel insecure by what we hear in Rwanda. There is harassment and persecution of journalists, opposition politicians and anyone who is critical of Kagame's government. We get more worried when Kagame follows up and kills his opponents living in exile". 49

Another reason for fleeing Rwanda includes unfair treatment of Hutu in Gacaca courts. ${ }^{50}$ An interviewee said: "I was imprisoned without any reason... and in the Gacaca courts there is no fair judgment especially for the Hutu" ${ }^{51}$ The refugees further said that the Gacaca courts and Ibuka commemorations have been used for settling personal vendetta. ${ }^{52}$ The refugees also noted that the Hutu who died are not remembered; only Tutsi are remembered. A refugee woman said: "....the minister said that it was a time to remember the Tutsi and not Hutu". ${ }^{3}$ This seemed unfair and politically oriented towards isolating the Hutu as the only culprits in the genocide, thus keeping them in constant fear of persecution even when they are refugees in Uganda.

Others fled because of lack of basic property for survival. They reported that their property was confiscated and had no means of livelihood. A respondent mentioned that his house had been taken by Tutsi returnees. He stated that "...some of our friends were killed, others arrested, people's houses and property were taken; the government is very hostile to Hutu....". 54

Refugees further mentioned ethnic segregation as a cause for their flight, and claimed that the Hutu were more subjected to poverty and ill treatment than the Tutsi. This was confirmed by other refugees: "Much as the government is talking of reconciliation and equal opportunities for all Rwandans, our Tutsi colleagues have more opportunities than us Hutu. There are more Tutsi in government, army, business and other sectors. Hutu are getting poorer and poorer each day that passes. When we complain, they accuse us of promoting the genocide ideology" ${ }^{55}$

It was noted that there were no peaceful means of solving ethnic differences in Rwanda and true reconciliation had not been achieved. True reconciliation was reported to be possible if Rwanda could remove restrictions on freedom of expression to enable national healing and reconciliation. Refugees stated: "All Rwandans need to sit together and look at their history objectively. We need to appreciate that both Hutu and Tutsi lost their people in the civil war and genocide. Denying this fact is unfair and will breed future problems. When we mention this they call us

\footnotetext{
${ }^{45}$ Interview with International Refugee Rights Initiative official, Kampala on $22^{\text {nd }}$ August 2010.

${ }^{46}$ Interview with the Settlement Commandant, Nakivale Settlement on $25^{\text {th }}$ June 2010; Interview with the Settlement Commandant, Nakivale settlement on $26^{\text {th }}$ August 2016.

${ }^{47}$ Ibid.

${ }^{48}$ Focus Group Discussion, Rubondo zone, Nakivale Settlement on $8^{\text {th }}$ July 2010; Focus Group Discussion, Rubondo zone, Nakivale settlement on $12^{\text {th }}$ July 2016.

${ }^{49}$ Focus Group Discussion, Sangano Base Camp, Nakivale settlement on $24^{\text {th }}$ June 2010; Focus Group Discussion, Sangano Base Camp, Nakivale settlement on $10^{\text {th }}$ June 2016.

${ }^{50}$ Gacaca is a neo traditional approach of transitional justice established in 2002 to try cases in post genocide Rwanda. Gacaca courts closed on $18^{\text {th }}$ June 2012. However, their legacy continues to haunt Rwandan refugees.

${ }^{51}$ Interview with a Refugee man, Rubondo zone, Nakivale Settlement on $10^{\text {th }}$ July 2010

${ }^{52}$ Focus Group Discussion, Sangano Base Camp, Nakivale settlement on $24^{\text {th }}$ June 2010; Focus Group Discussion, Rubondo zone, Nakivale settlement on $12^{\text {th }}$ July 2016; Focus Group Discussion, Oruchinga settlement on $29^{\text {th }}$ August 2016.

${ }^{53}$ Interview with a Refugee Woman, Sangano Base Camp zone on $22^{\text {nd }}$ June 2016.

${ }^{54}$ Interview with a Refugee man, Kigali zone, Nakivale Settlement on $23^{\text {rd }}$ June 2010; Interview with a refugee man, Rubondo zone, Nakivale settlement on $30^{\text {th }}$ January 2018.

${ }^{55}$ Focus Group Discussion, Juru Zone, Nakivale Settlement on 30 ${ }^{\text {th }}$ June 2010; Focus Group Discussion, Sangano Base Camp, Nakivale Settlement on $10^{\text {th }}$ June 2016.
} 


\section{killers and genocidaires". ${ }^{56}$}

Refugees claimed that they did not have freedom of expression in Rwanda and were worried about the wrong picture the Rwandan government had painted to the international community that did not reflect the reality on the ground. "We have constantly told UNHCR and OPM that there is no freedom of expression and speech in Rwanda. If you speak out your mind they regard you as an enemy. Yet there are critical issues we have to talk about as Rwandan citizens. Kagame is very smart with his propaganda. He has convinced the whole world that the country is peaceful. But the truth on the ground is that he is a dictator and killer". ${ }^{57}$

The reception in Rwanda was reported to be bad by the refugees who had returned and came to Uganda. One of the respondents said: "I didn't have where to settle and when I asked for my father's land at the sub county, they put me in prison. I decided to return to Uganda". ${ }^{58}$ The same point was raised by another recycler: "I am one of the people who returned to Rwanda in 2005. Unfortunately, life was hard for me. I was taken to prison and tortured by prison authorities. Before being taken to prison, I tried to claim my piece of land but I was harassed and labeled a killer. I approached the authorities for assistance but all in vain". ${ }^{59}$

The above views of refugees are confirmed by stakeholders. One of the Uganda security officials mentioned that "we hear there is mistreatment of the Hutu when they return. There is bias at home that refugees living abroad have painted a bad image of Rwanda. It is possible that those who return are looked at with suspicion". ${ }^{60}$ Another respondent argued that refugees who have stayed outside for long are seen by Kigali as either running away from justice or not patriotic ${ }^{61}$ Other sources have confirmed the views of refugees about socio-economic and political conditions in Rwanda. ${ }^{62}$

\subsection{Local and Surrounding Dynamics}

\subsubsection{Conflicts with Fellow Rwandans}

Nakivale and Oruchinga settlements have experienced conflicts between Rwandan Tutsi and Hutu. The former came to Uganda in 1959 and subsequent years while the latter arrived in and after 1994. The two groups have been involved in land conflicts especially in Nakivale. The Hutu accuse Tutsi herdsmen of deliberately allowing cattle destroy their crops. In addition, there was suspicion between the two groups. The Tutsi are accused of being President Kagame's spies in the settlements. The refugees argued that all their activities and movements were closely monitored by Rwanda through the Tutsi. ${ }^{63}$ One refugee man claimed: "All of us are being monitored by Rwanda. We cannot engage in any activity of fighting the Rwandan government. We will be killed. Our fellow Rwandan Tutsi who live here as Ugandans report to Kagame on everything happening in Nakivale. We are worried of them but we have no option". ${ }^{64}$

Rwandan Tutsi have Ugandan de facto citizenship. Although they were not officially/legally granted citizenship in Uganda, they were able to get citizenship through unofficial means. Some of these Tutsi were said to be having government jobs in Rwanda and traveled there regularly. A refugee man noted: "The Tutsi travel to Rwanda regularly to work. They come to visit their counterparts in Uganda. In the process, it is easy for them to spy on

\footnotetext{
${ }^{56}$ Focus Group Discussion, Sangano Base Camp, Nakivale Settlement on $24^{\text {th }} J u n e$ 2010; Focus Group Discussion, Juru zone, Nakivale Settlement on $30^{\text {th } J u l y ~} 2016$.

${ }^{57}$ Focus Group Discussion, Rubondo zone, Nakivale Settlement on $8^{\text {th }}$ July 2010; Focus Group Discussion, Oruchinga settlement on $29^{\text {th }}$ August 2016.

${ }^{58}$ Focus Group Discussion, Sangano Base Camp, Nakivale Settlement on $24^{\text {th }}$ June 2010.

59 Interview with a recycler, Kabazana village, Nakivale Settlement on $14^{\text {th }}$ June 2016.

${ }^{60}$ Interview with District Police Commander, Isingiro District, Kabingo Trading Centre on $20^{\text {th }}$ June 2010.

${ }^{61}$ Interview with a Protection Officer, Centre for Refugee Rights, Mbarara on $1^{\text {st }}$ July 2016.

${ }^{62}$ Fahamu Refugee Programme (2011), "Rwanda; Cessation of Refugee Status is Unwarranted - Memo of Fact and Law", September, available at: http://www.refugeelegalaidinformation.org/sites/srlan/files/fileuploads/Memo\%20of\%20Fact\%20and\%20 Law.pdf [accessed on 27 January 2014];International Refugee Rights Initiative, Refugee Law Project \& Social Science Research Council, "A Dangerous Impasse”, op.cit; Straus Scott \& Waldorf Lars (Eds) (2011), Remaking Rwanda: State Building and Human Rights After Mass Violence, Madison \& London, The University of Wisconsin Press; Reyntjens Filip (2013), Political Governance in Post-Genocide Rwanda, New York, Cambridge University Press.

${ }^{63}$ The Rwandan government is suspicious of the Rwandan refugees outside their country of origin. The current government officials including President Kagame in Kigali were once refugees in Nakivale. The 1990 invasion by the RPF was planned and organized with the Tutsi refugees living in Nakivale and other areas in Uganda.

${ }^{64}$ Interview with a refugee man, Kigali village, Nakivale Settlement on $17^{\text {th }}$ June 2016.
} 
us". ${ }^{65}$ These claims were raised by most interviewed refugees.

The above refugee claims were confirmed by sources within the OPM, NGO officials and local hosts, who acknowledged that Rwandan Hutu-Tutsi tensions existed in Nakivale and Oruchinga settlements. Other sources have made a similar argument that Rwandan conflicts are fought out on the Ugandan territory with Nakivale being the main theatre. ${ }^{66}$

\subsubsection{Conflicts with Other Refugee Nationalities}

Insecurity was also caused by the conflicts with other refugee nationalities. This was as a result of the diversity of the refugee population from DRC, Rwanda, Burundi, Somalia, Ethiopia, Sudan and Eritrea. The refugees inevitably compete for the limited resources available like land, water and other services. The competition results into tensions, fighting and murder which affect the security of refugees. There were notable land conflicts between Rwandan and Congolese refugees. After the ban on cultivation for Rwandans, land was transferred to Congolese refugees. Rwandans accuse Congolese (popularly known as Banyamulenge and Bakongomani) ${ }^{67}$ of taking over their land. They noted that: "We used to access land and grow our crops. We would then get food for our children. When the Banyamulenge came, they took our land. The Banyamulenge tell us that we don't have land here and should go back to Rwanda. This hurts us but we cannot do anything". ${ }^{68}$ In a FGD refugees said: "The coming of the Bakongomani here in Nakivale has been bad news to us. They have taken all the land that belonged to us. We are now beggars in the face of other refugees. The Bakongomani laugh at us that we are landless. At times we fight with them". ${ }^{69}$ Although Congolese refugees are not to blame for the land conflicts, the fact that they were given land originally owned by Rwandans automatically made them enemies.

Rwandans were also suspicious of Congolese Tutsi refugees (Banyamulenge) from Eastern DRC. The Banyamulenge were suspected of being Kagame's spies since they are Tutsi. Refugees noted: "We regard Banyamulenge from Congo as our enemies because they are an ally of Kagame". ${ }^{70}$ This suspicion and fear of Congolese refugees is understandable given the ethnic similarities between the Banyamulenge and the Rwandan Tutsi.

The settlement commandant confirmed that there were conflicts between Rwandan and Congolese refugees fueled by competition for land, ethnic tensions and suspicion. ${ }^{71}$ This view is shared by other sources. ${ }^{72}$

\subsubsection{Conflicts with Local Hosts}

Nakivale and Oruchinga settlements have experienced conflicts between local hosts and refugees. Although a good number of refugees reported to be happy staying with Ugandans, a significant number argued that conflicts had greatly affected their relationship. They observed that there was increased enmity over land, abuse and continuous incitement from local hosts. In a FGD they noted that: "Our relationship with Ugandans used to be okay. However, many of them started coming here in the settlement in search of land. The local hosts argued that Nakivale land was theirs and refugees should go back to their countries. We opposed them and this led to fighting and quarrels". ${ }^{73}$ The same view was raised by refugees in Juru zone: "There are land conflicts between refugees and Ugandans. We all claim the same pieces of land. Last month the Settlement Commandant came to chase away the

\footnotetext{
${ }^{65}$ Interview with a refugee man, Rubondo zone, Nakivale Settlement on $7^{\text {th }}$ July 2010; Interview with a refugee woman, Kigali village, Nakivale settlement on $27^{\text {th }}$ January 2018.

${ }^{66}$ For more discussion refer to: Emmanuel Bagenda, Angela Naggaga \& Elliott Smith (2003), "Land Problems in Nakivale Settlement and the Implications for Refugee Protection in Uganda", Refugee Law Project Working Paper No. 8, May, available at: http://www.refugeelawproject.org/working_papers/RLP.WP08.pdf; Refugee Law Project (2004), Land and Ethnicity in Nakivale Refugee Settlement: The Need to Resolve Competing Claims and Address Tensions, $27^{\text {th }}$ October, available at http://www.refugeelawproject.org/files/archive/2004/RLP.nakivale.land.pdf [accessed on 1st December 2016].

${ }^{67}$ The term Banyamulenge refers to Tutsi Congolese refugees in Nakivale. It should be noted that this is an extension of the original meaning of this term, as the Banyamulenge are in reality a small group of Tutsi originally from Rwanda who live on the Itombwe highlands in South Kivu. During interviews, Rwandan refugees referred to Tutsi Congolese refugees as Banyamulenge and non-Tutsi Congolese as Bakongomani.

${ }^{68}$ Focus Group Discussion, Juru zone, Nakivale Settlement on $10^{\text {th }}$ July 2010; Focus Group Discussion, Sangano Base Camp, Nakivale settlement on $10^{\text {th }}$ June 2016.

${ }^{69}$ Focus Group Discussion, Sangano Base Camp, Nakivale Settlement on $24^{\text {th }}$ June 2010.

${ }^{70}$ Focus Group Discussion, Rubondo zone, Nakivale Settlement on $12^{\text {th }}$ July 2016.

${ }^{71}$ Interview with Settlement Commandant, Oruchinga settlement on $29^{\text {th }}$ August 2016; Interview with a Settlement Commandant, Nakivale settlement on $28^{\text {th }}$ January 2018.

${ }^{72}$ Ahimbisibwe Frank (2015), The Host State and Refugee Security in Uganda: The Case of Rwandan Refugees in Nakivale Settlement, Doctoral Dissertation, Unpublished, Mbarara, Mbarara University of Science and Technology; Refugee Law Project, "Land and Ethnicity in Nakivale", op.cit.

${ }^{73}$ Focus Group Discussion, Sangano Base Camp, Nakivale Settlement on $24^{\text {th }}$ June 2010.
} 
Ugandans but they refused to leave. They are telling us that instead refugees are the ones to vacate their land. Recently a group of Ugandans attacked cows belonging to a refugee and injured them. The case has been registered at Juru police post". ${ }^{74}$

The refugees mentioned one incident between refugees and one local Ugandan. The latter accused the former of settling on his land illegally for 3 years. This local Ugandan brought soldiers from Mbarara to evict the refugees. This resulted into injuries and destruction of property. However, the refugees reported the case to the settlement commandant who intervened on the side of refugees to stay on the land. The case was however taken to court by this Ugandan man. ${ }^{75}$

The existence of land conflicts has been confirmed by OPM, Isingiro district officials and local hosts. A district official noted: "Here in Isingiro district we have a challenge of land conflicts between the refugees and local hosts. What is surprising us is that some local Ugandans have land titles here in Nakivale and we wonder how they got them. Nakivale land is government land and it is not possible to acquire land titles. With many cases of corruption here in Uganda anything is possible. Land conflicts have led to insecurity here in Nakivale and it is common to hear of fighting, murder and destruction of property" ${ }^{76}$

Some respondents reported that in the year 2009, a group of local people, mainly Banyankore went to the settlement to claim the land that 'belonged to them'. They were aggrieved that refugees were using it while Ugandans did not have land to use. One female Ugandan argued: "Uganda is a funny country; how can you give land to refugees when nationals do not have. It is like a parent who loves the neighbor's children more than her own. We shall not accept this. Refugees should go back to where they came from". ${ }^{77}$ The same sentiment was echoed by a Ugandan man: "We have land conflicts between refugees and the nationals. The root causes are unclear boundaries and corruption. The Camp Commandant wanted to put refugees in Yowasi's land and we demonstrated and fought. The commandant later gave up. We later heard that the commandant had been bribed by refugees. As Ugandans we shall not tolerate this unfairness and injustice". ${ }^{78}$

\subsubsection{Large and Open Settlement}

Nakivale is a large and open settlement where there is free entry and exit and as such it is not easy to ensure security. The settlement is 84 square kilometers large with over 115,000 refugees $^{79}$. It is difficult to maintain security in this vast settlement with a significant number of nationals without entry and exit control. The refugees noted that insecurity is caused by the large size of Nakivale. ${ }^{80}$ In a FGD, the refugees noted that the settlement was not fenced and people move in and out any time of the day without any hindrance. They argued that this has given their enemies easy access to the settlement." ${ }^{" 81}$ The refugees in Oruchinga also expressed the same fears of living in an open and unfenced settlement. ${ }^{82}$

The Settlement Commandant noted that: "One of the causes of insecurity here in Nakivale is the big and open settlement. Nakivale has so many entry and exit points that are not monitored. You cannot tell who comes in and goes out. It's a big challenge on our part to ensure security to the refugees. I think there is need to fence the settlement the way Kenya and Tanzania do it" ${ }^{83}$ The same view was shared by a security official: "Insecurity in Nakivale is partly due to the vast and open settlement where there is free entry and exit. Movements are not regulated. We know of refugee groups that drive in and out of the settlement in the middle of the night. Surely, how can we ensure security when refugee movements are not monitored and regulated? We are sitting on a time bomb". ${ }^{84}$

In countries like Kenya and Tanzania, measures like fencing camps and limiting movements have helped in ensuring security. However, Kenya and Tanzania have faced challenges of ensuring security despite the presence of fences in the refugee camps. It is difficult to ensure security in a big and open settlement than in a closed camp.

\footnotetext{
${ }^{74}$ Focus Group Discussion, Juru Zone, Nakivale Settlement on 30 ${ }^{\text {th }}$ June 2010.

${ }^{75}$ Focus Group Discussion, Kabazana village, Nakivale settlement on $15^{\text {th }}$ June 2016.

${ }^{76}$ Interview with Isingiro District Chairperson, Isingiro District Headquarters on $17^{\text {th }}$ July 2016.

${ }^{77}$ Interview with a Female Ugandan, Kyakabindi Village, Ngarama Sub county, Isingiro District on $16^{\text {th }}$ July 2016.

${ }^{78}$ Interview with a Ugandan Man, Rwabahinda Village, Mbale Sub county, Isingiro District on $15^{\text {th }}$ July 2010.

${ }^{79}$ According to the Deputy Settlement Commandant, Nakivale settlement, this number of refugees is as of $3^{\text {rd }}$ August 2016.

${ }^{80}$ Focus Group Discussion, Kabazana village, Nakivale settlement on $15^{\text {th }}$ June 2016.

${ }^{81}$ Focus Group Discussion, Rubondo zone, Nakivale settlement on $12^{\text {th }}$ July 2016.

${ }^{82}$ Focus Group Discussion, Oruchinga settlement on $29^{\text {th }}$ August 2016.

${ }^{83}$ Interview with Settlement Commandant, Base Camp, Nakivale Settlement on $26^{\text {th }}$ August 2016.

${ }^{84}$ Interview with the District Internal Security Officer, Isingiro District, Kabingo Town, on $5^{\text {th }}$ July 2016.
} 
According to UNHCR, "camps of over 20,000 people should be avoided" ${ }^{85}$ Crisp has argued that while UNHCR does not give any reason for this recommendation, there is a general understanding within the organization that larger camps have several disadvantages: their environmental impact is greater than that of smaller camps; they impinge to a greater degree on the local population; they provide a less familiar and comfortable way of life for refugees, most of whom are of rural origin; they are consequently more prone to social unrest and are simultaneously more difficult to police. ${ }^{86}$

\subsubsection{Composition of Refugee Population}

As earlier noted, Nakivale Settlement has a diverse population with refugees from DRC, Rwanda, Burundi, Somalia, Ethiopia, Sudan and Eritrea. In Oruchinga, the main refugee nationalities are Rwandans, Burundians and Congolese. With this large population and unclear land boundaries, the possibility of conflict, often manifesting itself in various forms of ethnic, social, economic, and political disputes become inevitable. One respondent noted: "Insecurity in Nakivale is caused by the presence of various refugee nationalities. These refugees are from different backgrounds and cultures. For example, Somalis regard other refugee nationalities as inferior and unclean. They do not want to mix freely with other groups of refugees. The other refugee groups call Somalis terrorists. This brings about misunderstanding and conflicts between different refugee nationalities" ${ }^{87}$ One refugee woman noted: "Suspicion and hatred among refugee groups has led to insecurity. Since we come from different countries, there are differences in religion, culture, customs, beliefs and language. These differences at times cause conflicts". ${ }^{8}$

The above views were reiterated by government officials. One official argued: "How do you expect to have peace and security in Nakivale with a population of close to 120,000 refugees? This is a big challenge. Remember these refugees have different backgrounds, experiences, beliefs and languages. These people look at each other as foreigners and strangers. You cannot expect them to live together harmoniously". 89

In addition, among the refugee groups are former soldiers, rebels, criminals plus traumatized refugees. Violence and fighting are more likely unless strong measures are put in place to prevent and resolve conflicts. Furthermore, former enemies are likely to live together in countries of asylum. As already mentioned, there are conflicts between Rwandan Hutu and Tutsi in Nakivale and Oruchinga settlements. This was noted by one respondent: "Insecurity in Nakivale and Oruchinga is brought about by former enemies living together in settlements. This leads to the transfer of conflicts from home to countries of asylum. Rwandan Hutu and Tutsi are an example". .0

The above findings confirm what Jeff Crisp had earlier found in Kenya, namely that

"with regard to the composition of the camps, there are some evident risks in the establishment of a camp such as Kakuma, where refugees from around ten different countries and 20 ethnic groups are obliged to live together especially when those refugees are members of communities which have good reason to distrust or even despise each other: Hutus and Tutsis; Amharas, Eritreans and Oromos; Sudanese Christians and Somali Muslims". 91

\subsubsection{Refugee Protests}

Refugee protests were another source of insecurity especially in Nakivale settlement. There were times when refugees would barricade all roads into the settlement to protest food-aid disruption. Other protests were caused by refugees' grievances like accidental death of their fellow refugees ${ }^{92}$ and conflicts between different refugee nationalities. A notable one was the 2009 protest in Nakivale settlement where Congolese refugees and to a small extent other refugee nationalities staged a protest over failure to get food supplies in the settlement. An interviewee said: "We had spent three months without any food supplies from government or any food relief or humanitarian agency". ${ }^{93}$ Another refugee added: "How do you expect refugees to be peaceful when they are hungry and desperate for food? A hungry person is an angry one".${ }^{94}$ Another respondent mentioned that "in 2009 we were demanding to

${ }^{85}$ UNHCR (1999), Handbook for Emergencies, Geneva, UNHCR: 137.

${ }^{86}$ Crisp Jeff, "Forms and Sources of Violence", op.cit: 69.

${ }^{87}$ Focus Group Discussion, Juru zone, Nakivale settlement on $30^{\text {th }}$ July 2016.

${ }^{88}$ Interview with a refugee woman leader, Kabazana village, Nakivale settlement on $14^{\text {th }}$ June 2016.

${ }^{89}$ Interview with Secretary for Defence, Isingiro District Local Government, Kabingo Town on $21^{\text {st }}$ August 2016.

${ }^{90}$ Interview with Refugee Desk Officer, Office of the Prime Minister, Mbarara on $22^{\text {nd }}$ July 2010.

${ }^{91}$ Crisp Jeff, "Forms and Sources of Violence", op.cit: 69.

${ }_{92}$ See Tumushabe Alfred (2011), "Nakivale Refugees and Police Clash”, Daily Monitor, Friday, $7^{\text {th }}$ January 2011.

${ }^{93}$ Interview with a refugee man in Juru zone, Nakivale on $2^{\text {nd }}$ July 2010.

${ }^{94}$ Interview with a refugee man, Kigali village, Nakivale on $25^{\text {th }}$ June 2010. 
be relocated to another country where we could be protected from hunger". ${ }^{95}$ This was further emphasized by refugees in a focus group discussion: "The 2009 protest was caused by lack of food here in Nakivale. The World Food Programme ran out of food supplies and this caused commotion. We Rwandan refugees did not actively participate for fear of being expelled. But in our hearts we supported the Congolese refugees who actively demonstrated. We were all faced with the problem of hunger". ${ }^{96}$

An OPM official noted that: "the 2009 protest was so serious that the local settlement and Isingiro police could not handle it. We had to get reinforcements of military police from Mbarara to stop the protest. Just like with other protests in Uganda, a number of refugees were injured, arrested and imprisoned". 97

\subsubsection{Armed Robbery, Theft and Murder}

A number of Rwandan refugees and Ugandans living in the settlement expressed fear moving at night because it was considered unsafe. One refugee man noted that: "We fear for our lives. There are cases of robbery at night. At times people are killed and we don't know who is responsible". ${ }^{98} \mathrm{In}$ a FGD refugees noted: "Although OPM and police have tried to ensure security, there are still cases of robbery, theft and murder". ${ }^{99}$

The local hosts also expressed their views on insecurity. A Ugandan male said: "it is very hard to move at night; for example recently some Ugandans were severely beaten and robbed of their money" ${ }^{100} \mathrm{~A}$ Ugandan woman noted: "Theft cases are common here. Refugees steal our food, goats and chicken. We can tell a difference between the time when refugees were few and now that the number has increased. Last week in Kankingi village, thieves were arrested and found with 10 stolen goats. One thief was hit and killed by a mob". ${ }^{101}$

A security official said: "Theft and murder are common in Nakivale. There are more of these cases in the refugee settlement. Both refugees and host communities are responsible for thefts. However, our security intelligence shows that there are more refugees involved in theft than the local hosts. These insecurity cases lead to loss of lives and property". ${ }^{102}$ Humanitarian officials said: "some of these refugees are former combatants, so we are cautious of our movements and by $7 \mathrm{pm}$ all vehicles should be already in the settlement". ${ }^{103}$ There was a problem of highway armed robbery ${ }^{104}$ said to be rampant between the late 1990s and mid-2000s until the intervention of Uganda police. These cases were common on the highway from Kabingo town to Rugaaga around Kahirimbi and Rwekubo trading centers.

According to the respondents, cases of highway robbery had reduced drastically but there were still a few cases reported. For example, during the time of data collection, there were reports of armed robbery, murder and theft in Nakivale around 15 times in a space of 2 months.

\subsubsection{Influence of Local Politics}

Some local politicians in Isingiro district were mobilizing local Ugandans against refugees mainly on the issue of land. In a FGD refugees noted: "Ugandans have grabbed settlement land. The influential politicians have bribed and are in possession of land titles. Many have come and settled on settlement land. Some are army officers who threaten refugees with murder and imprisonment. This is what I call harassment of refugees by local hosts. Instead of welcoming and assisting refugees, the locals are busy grabbing their land" ${ }^{105} \mathrm{~A}$ refugee man noted "The local leaders in Isingiro have mobilized the local hosts to attack us. They say we are settled on Uganda's land. This has fueled land conflicts in Nakivale". ${ }^{106}$ In a FGD refugees said: "We were victims of harassment by a powerful district official connected to the army. He fenced all our land. We mobilized ourselves and destroyed the fence and poles. We were beaten by the army and police and some refugees sustained injuries. Later, the district and police officials

\footnotetext{
95 Interview with a refugee woman, Juru zone, Nakivale on $3^{\text {rd }}$ July 2010.

${ }^{96}$ Focus Group Discussion, Juru zone, Nakivale Settlement on $30^{\text {th }}$ July 2016.

${ }^{97}$ Interview with Refugee Desk Officer, OPM, Mbarara on $27^{\text {th }}$ August 2016.

${ }^{98}$ Interview with a refugee man, Rubondo zone, Nakivale settlement on $12^{\text {th }}$ July 2016.

${ }^{99}$ Focus Group Discussion, Oruchinga settlement on $29^{\text {th }}$ August 2016.

${ }^{100}$ Interview with a Ugandan male, Kabwera village, Rushasha sub-county on $13^{\text {th }}$ July 2010.

${ }^{101}$ Interview with a Ugandan woman, Bururuma village, Rugaaga sub-county on $20^{\text {th }}$ July 2016.

102 Interview with Deputy District Police Commander, Isingiro District, KabingoTown on $20^{\text {th }}$ June 2010.

${ }^{103}$ Interview with UNHCR staff, Nakivale Settlement on $5^{\text {th }}$ July 2016.

104 Office of the President, Republic of Uganda, Report on the Investigative Findings on Nakivale and Oruchinga Refugee Settlements carried out between 08/04/2005 to 10/04/2005, Ref. No. SPA/PA/18/07/02/05, dated 22/03/2005, on file with the author.

${ }^{105}$ Focus Group Discussion, Sangano Base Camp, Nakivale Settlement on $10^{\text {th }}$ June 2016.

${ }^{106}$ Interview with a refugee man, Juru zone, Nakivale settlement on $4^{\text {th }}$ July 2016; Interview with a refugee man, Kabazaana village, Nakivale settlement on $28^{\text {th }}$ January 2018.
} 
intervened to ensure security". ${ }^{107}$

A newspaper reported that a local district councilor was busy mobilizing nationals against refugees in what he called harassment of Ugandans by refugees. ${ }^{108}$ He noted: "We will not allow refugees to harass Ugandans when we are watching. Ugandans will not become 'refugees' in their own country. I was elected to represent the people of Isingiro at the district. I have an obligation to represent their interests including land. We have taken the case to Mbarara High Court and we want court to pronounce itself on the issue of land ownership in Nakivale". ${ }^{109}$ The district councilor worked with his supporters to evict refugees. ${ }^{110}$ Other sources have written on how some politicians had fenced settlement land and brought in the army and police to chase away refugees. ${ }^{111}$ This is in line with the argument that local politics affects refugees especially when local politicians attack refugees using them as scapegoats of the problems affecting local hosts. ${ }^{112}$

\subsection{Host State}

\subsubsection{Shortcomings in Ensuring Security}

Uganda has experienced shortcomings and challenges in ensuring the physical security of refugees in Nakivale and Oruchinga settlements. In a FGD, refugees stated that security was not good because they often got intelligence people from Rwanda coming around to spy on them. They noted: "The security in the settlement is not the best; we live in constant fear of being abducted by Rwanda security operatives. The settlement is too open to hide from our enemies. Sometimes you see people you don't know coming in the settlement. Besides there is discrimination against us which makes us feel insecure. We feel Uganda has not protected us well". ${ }^{113}$ The same fears were raised by another group of refugees: "We thank the Uganda government for its hospitality towards refugees. However, we feel the government has to do more and ensure security in Oruchinga. We are threatened by Rwandan security agents. They spy on us and kidnap our colleagues. The prospect of forced repatriation also threatens us. We request more protection from the government". ${ }^{114}$ Another respondent mentioned that "security is not good because there are robbers and thieves who disturb us especially at night". ${ }^{115}$

The local hosts reiterated the refugees' views. A Ugandan male said: "there are cases of insecurity here in Nakivale; for example in Kibwera last year two Congolese killed their fellow Congolese". ${ }^{116}$ Another respondent noted: "It is rare to spend a whole month here in Nakivale without hearing of theft, robbery or murder. These are common cases that we are used to". ${ }^{117}$ The same view was echoed: "Security is poor and there are cases of theft and robbery. Last year there was a refugee army deserter who had a gun and used it to rob people's homes at night. He was later arrested, tried and is now in prison". ${ }^{118}$

NGO and OPM staff raised the same view on insecurity. One of the humanitarian officials noted that "security is not fine, much as responsible officers try to do their work". ${ }^{119}$ She further noted: "We get cases of armed robbery; cases of stealing like a gun from a policeman attached to Juru police post in 2010, cases of fighting are there though not frequent". ${ }^{20}$

\footnotetext{
${ }^{107}$ Focus Group Discussion, Juru zone, Nakivale Settlement on $30^{\text {th }}$ June 2010.

108 Alfred Tumushabe (2011), "Refugees Harass us- Isingiro Locals", Daily Monitor, Monday, $31^{\text {st }}$ October 2011: 14.

109 Phone interview with Youth Councillor, Isingiro District Local Government on $4^{\text {th }}$ November 2011.

110 Phone interview with the Settlement Commandant, Nakivale Settlement on $3^{\text {rd }}$ November 2011. This phone interview was prompted by the story that appeared in a Daily Monitor Newspaper on Monday, October $31^{\text {st }} 2011$, titled "Refugees Harass Us-Isingiro Locals".

${ }^{111}$ See Ahimbisibwe Frank (2013), "The Effect of Land Conflicts on the Livelihoods of Refugees: Implications for Refugee Protection in Uganda", Research Journal of Social Science and Management, Vol. 3 No.6, October: 23; Emmanuel Bagenda, Angela Naggaga\& Elliott Smith, "Land Problems in Nakivale Settlement", op.cit.

${ }^{112}$ See Milner, James, "Sharing the Security Burden", op.cit; Milner, James (2009), Refugees, the State and the Politics of Asylum in Africa, Basingstoke: Palgrave Macmillan; Rutinwa, Bonaventure (1999), "The End of Asylum? The Changing Nature of Refugee Policies in Africa", New Issues in Refugee Research, Working Paper No. 5, Geneva, UNHCR, May.

${ }^{113}$ Focus Group Discussion, Sangano Base Camp, Nakivale Settlement on $10^{\text {th }}$ June 2016.

${ }^{114}$ Focus Group Discussion, Oruchinga settlement on $29^{\text {th }}$ August 2016.

115 Interview with a refugee woman, Rubondo zone, Nakivale on $7^{\text {th }}$ July 2010.

116 Interview with a local Ugandan, Kashojwa village, Nakivale on $17^{\text {th }}$ July 2010.

117 Interview with a Ugandan Man, Kahirimbi cell, Isingiro Town Council on $16^{\text {th }}$ July 2016.

118 Interview with a Ugandan Man, Kyakabindi village, Ngarama Sub County on $16^{\text {th }}$ July 2010.

119 Interview with a Legal Officer, GIZ, Nakivale on $20^{\text {th }}$ July 2016.

${ }^{120}$ Ibid.
} 


\subsubsection{Small Police Force}

In addition, insecurity is fueled by the small number of police officers compared to the number of refugees in settlements. In 2010, there were 2 police officers in Rubondo Zone (the other 2 officers had gone to Masindi Police training school for training), 2 in Juru, 2 in Kahirimbi, 5 in Kashojwa and 4 in Kabahinda. Under normal circumstances a police post should have 6 police personnel. ${ }^{121}$ Nakivale was hosting close to 70,000 refugees, a number too large to be protected by a mere 15 police officers. By the end of 2016, there were 45 police personnel protecting 120,000 refugees. ${ }^{122}$ According to international standards, the acceptable ratio is 1 police officer for 500 people. ${ }^{123}$ Going by this standard, the police-people ratio $(1: 2667)$ in Nakivale was far below the internationally acceptable standards. 240 police personnel were required to meet the international standards. In Oruchinga, there were 15 police personnel for 7200 refugees, a ratio of 1 police officer for 480 people. This ratio is acceptable under international standards.

The respondents further talked of corruption and failure by the police to protect the refugees. One refugee man said that "police officers are few and poorly facilitated. Nakivale is a large area which needs many police officials". ${ }^{124}$ A refugee woman agreed: "We feel insecure because of few police men around. We fear that any time Kagame will come and put us on lorries and take us back to Rwanda. He has been threatening that he will come and take us by force. We need more police officers to protect us. At the moment we live under God's mercy". ${ }^{125}$

In addition, police did not have enough facilities in terms of fuel and vehicles to carry out their work. In 2010, police used motorcycles to patrol the settlement. By 2016, police had acquired a car to assist in their operations. The refugees talked of cases where police officers asked for money to provide them with a service. This left the majority of the poor refugees without access to police services and assistance. One refugee woman said: "The police officers are not enough here in Nakivale. When you go there with a problem, they ask you for money. Refugees are poor people. They do not have money to give to police officers" ${ }^{126} \mathrm{~A}$ refugee man noted: "Police in the settlement is corrupt. Last year I was attacked by thieves at night. When I called one of our police officers, he told me there was no fuel in the motorcycle. He said I had to buy fuel. The police men came the following day at 11:00 am. Surely did the police expect to find thieves waiting for them? The response by police is very slow and at times not there at all". ${ }^{127}$ In addition in 2010 there was only one police woman. More than half of the refugee population in Nakivale settlement are women. By 2016, the number of police women stood at $6 .{ }^{128} \mathrm{The}$ low number of police women is another flaw in the host state's duty to protect.

\subsubsection{Government Ban on Cultivation}

As already mentioned, a cultivation ban was imposed on Rwandan refugees under the cover of forcing them to return. Refugees had this to say: "Life is very hard without land. We used to cultivate and get food for our families. Now we depend on the mercy of World Food Programme. The assistance we get is very little. We request the government to revise the ban on cultivation". ${ }^{129}$ One refugee woman lamented that "the ban on cultivation has made us turn into beggars. Can you imagine people with hands and legs to become beggars? What did Rwandans do to deserve all this suffering?". ${ }^{130}$ The ban negatively affected Rwandan refugees in Nakivale settlement since they no longer had access to adequate food. There was increased food insecurity, domestic violence, theft and land conflicts between Rwandan and Congolese refugees. ${ }^{131}$

Stakeholders agreed with refugee views. One respondent commented that "to take away people's livelihoods by implementing a farming ban is a short-sighted policy which only contributes to fueling tensions among refugees". ${ }^{132} \mathrm{An}$ aid worker said: "The ban on cultivation is very unfair and it discriminates against Rwandan

\footnotetext{
${ }^{121}$ Interview with Settlement Commandant, Nakivale settlement on $25^{\text {th }}$ June 2010.

${ }^{122}$ Interview with Nakivale Settlement Commandant, Mbarara on $28^{\text {th }}$ January 2018.

${ }^{123}$ Namanya Benjamin (2009), "Urbanization and Security in Kampala City, Uganda" in Gary Cordner et.al, Urbanization, Policing and Security: Global Perspectives, London \& New York, CRC Press, Taylor \& Francis Group

${ }^{124}$ Interview with a refugee man, Juru Zone, Nakivale Settlement on $1^{\text {st }}$ July 2010.

125 Interview with a refugee woman, Karitima village, Rubondo zone, Nakivale Settlement on $7^{\text {th }}$ July 2010.

${ }^{126}$ Interview with a refugee woman, Kigali Zone, Nakivale Settlement on $24^{\text {th }}$ June 2010.

${ }^{127}$ Interview with a refugee man, Karitima village, Rubondo zone, Nakivale Settlement on $8^{\text {th }}$ July 2010.

${ }^{128}$ Interview with Nakivale Settlement Commandant, Mbarara on $19^{\text {th }}$ January 2016.

${ }^{129}$ Focus Group Discussion, Rubondo zone, Nakivale Settlement on $12^{\text {th }}$ July 2016.

${ }^{130}$ Interview with a refugee woman, Kigali village, Nakivale Settlement on $22^{\text {nd }}$ June 2010.

131 As said earlier, land used by Rwandan refugees was transferred to Congolese refugees. This naturally led to tensions as the former looked at the latter as 'land grabbers' and responsible for their suffering.

${ }^{132}$ Interview with a Protection Officer, Centre for Refugee Rights, Mbarara on $1^{\text {st }}$ July 2016.
} 
refugees on the basis of nationality. This is a violation of the refugee and human rights law principle of nondiscrimination. Obviously this policy has contributed to insecurity at least from a human security perspective". ${ }^{133}$

Furthermore, aid agencies like the World Food Program and UNHCR had limited and rather inflexible budgets and it was difficult for them to quickly implement stop-gap measures when changes in policy - like the farming ban - took place. An aid agent observed: "It is hard for humanitarian agencies to respond faster by increasing assistance to Rwandans because of the challenges of getting donations. But also, organizations plan and budget well in advance. It is hard for them to change budgets and plans to cater for a specific group of refugees. Currently Rwandan refugees get assistance on the assumption that they are able to supplement". ${ }^{134}$ In the words of one respondent, "the policy of ban on cultivation has caused more insecurity in Nakivale as Rwandan refugees have resorted to illegal means of survival". ${ }^{135}$ Other sources have reported the food insecurity of Rwandan refugees. ${ }^{136}$

\subsubsection{Forced Repatriation and Deadlines to Return}

The threat of forced repatriation has led to insecurity and fear among Rwandan refugees in Nakivale and Oruchinga. The majority of refugees noted that they were living in constant fear of being forced to return to Rwanda. In addition, the pending cessation of refugee status has caused uncertainty and tension. Others stressed that they had resorted to sleeping in the bush for fear of being rounded up, put on trucks and returned to Rwanda. Refugees noted: "We are afraid of the cessation clause. We know they will force us to go to Rwanda and be killed by Kagame. Some of us are thinking of drowning in Lake Nakivale instead of being returned to Rwanda". ${ }^{137}$ In another FGD the same sentiments were expressed: "In 2007, our colleagues in Kibati were forcefully returned to Rwanda in the middle of the night. We know any time they are coming for us. This has caused a lot of uncertainty and fear in the settlement". ${ }^{138}$

The fears of refugees were understandable given the forced return of Rwandan asylum seekers and refugees on $14^{\text {th }}$ July $2010 .{ }^{139}$ In the aftermath of this forced return, many Rwandan refugees were not sleeping in their homes. In fact, I was called during the night of $17^{\text {th }}$ July 2010 by a group of Rwandan refugees living in Juru zone, Nakivale settlement that they were hiding in the bush near Lake Nakivale. The refugees had run away from their homes because of a rumor that the police and army were planning to forcefully return them.

Forced return of refugees is a violation of refugee law and it puts many refugees at risk of being persecuted on return to Rwanda. The majority of the returned "rejected asylum seekers" in July 2010 had not exhausted the appeal process. ${ }^{140}$ According to the Uganda Refugees Act, "an applicant aggrieved by the decision of the Refugee Eligibility Committee may appeal to the Appeals Board within thirty days after receipt of the notice of the decision of the Eligibility Committee". ${ }^{141}$

According to the 1951 UN Refugee Convention, the obligation of the state is "not to return or expel the refugee to where his or her life would be at risk for reasons of race, nationality, religion and membership of a particular social group or political opinion". ${ }^{142}$ The forced return of Rwandan refugees and asylum seekers is a violation of the principle of non-refoulement.

\subsubsection{Close Relationship with Rwanda}

Uganda and Rwanda enjoy fairly a close relationship at least on the surface. This has affected Rwandan refugees

\footnotetext{
133 Interview with a Refugee Law Project official, Mbarara on $26^{\text {th }}$ July 2016.

${ }^{134}$ Interview with an official of GTZ, Base Camp, Nakivale Settlement on $6^{\text {th }}$ July 2010.

${ }^{135}$ Interview with an Internal Security Organization (ISO) Officer, Kabingo Town, Isingiro District on $20^{\text {th }}$ July 2010.

${ }^{136}$ See OPM, UNHCR and the World Food Programme (2010), The Joint Assessment Mission Final Report, March; Amnesty International (2011), Memorandum to the Government of Uganda about the Cessation of Refugee Protection for Rwandans, Index: AFR 59/021/2011, London, Amnesty International Publications, December.

${ }^{137}$ Focus Group Discussion, Sangano Base Camp, Nakivale Settlement on 24 ${ }^{\text {th }}$ June 2010.

${ }^{138}$ Focus Group Discussion, Oruchinga settlement on $29^{\text {th }}$ August 2016.

139 On July $14^{\text {th }} 2010$, the researcher and his team were in Nakivale settlement when the forced return of Rwandan asylum seekers and some refugees was carried out. The team heard gun shots and saw a good number of Rwandan refugees running away in different directions, some towards Lake Nakivale purportedly to commit suicide. I later saw a convoy of many lorries carrying Rwandans around Juru Trading Centre at around 1600 hours (4:00 pm local time). I counted around 15 lorries being escorted by Ugandan Police and OPM cars. Surprisingly UNHCR cars were part of this convoy. The team also observed one Rwandan man jumping off the truck and dying instantly on the spot.

${ }^{140}$ In an interview with a senior officer in the Office of the Prime Minister, he regretted the denial of Rwandan asylum seekers the right of appeal. He acknowledged that the asylum seekers could have been returned to Rwanda where the likelihood of persecution upon return was very high.

${ }^{141}$ Section 21(1) of the 2006 Uganda Refugees Act.

${ }^{142}$ See Article 33 (1) of the 1951 UN Convention Relating to the Status of Refugees.
} 
living on Ugandan soil. The refugees revealed that there was a strong collaboration between the two neighbors on the way they were being treated. They noted that "it was easy for Rwandan security agents to harass us because of the close relationship between the two governments". ${ }^{143}$ Another FGD noted: "The close relationship between the two countries is responsible for our suffering. Uganda government officials listen to their Rwandan colleagues during meetings. That is why we were stopped from cultivation and are being forced to return". ${ }^{144}$ The refugees believed that it was easy for Rwanda to influence policy making on refugees in Uganda.

As already mentioned, Harrell-Bond made this observation regarding the close relationship between Uganda and Rwanda and how this has negatively affected the security of refugees. One respondent agreed with this view: "one of the problems affecting Rwandan refugees is the close relationship between Uganda and Rwanda. Uganda seems to be implementing exactly what Rwanda wants. Uganda has sacrificed refugee rights at the altar of diplomatic relations". ${ }^{145}$ However, even when Uganda and Rwanda fell out for the period between 1999 and $2006{ }^{146}$, this did not interrupt efforts by the Rwandan intelligence to harass refugees in

Uganda. ${ }^{147}$

\subsubsection{Discrimination and Harassment by Office of the Prime Minister (OPM)}

The Office of the Prime Minister has orchestrated forms of discrimination against Rwandans. For example, the ban on cultivation, reduction in food rations, denial of travel documents and verbal attacks were implemented with the full knowledge of the OPM. The majority of the refugees noted that they were denied audience/hearing by officials in OPM especially on their challenges and security concerns. ${ }^{148}$ It was further revealed that the OPM was responsible for the forced return of Rwandans on $14^{\text {th }}$ July $2010 .{ }^{149} \mathrm{~A}$ respondent asked: "How can OPM officials participate in the forced return of our fellow Rwandans by lying to them that they were going to receive ration cards and food? How can OPM escort them well aware that Rwanda is not peaceful? To me the OPM has neglected and left us as orphans". ${ }^{150}$ Refugees in a FGD said: "Because of discrimination by OPM officers, refugees no longer respect them. They tell us that we have no space in Nakivale and government does not want us here. They tell us that our home is in Rwanda. They make these statements almost every day". ${ }^{151}$

NGO officials shared the views of refugees. One respondent noted: "Uganda is praised internationally for her open asylum policies. However, its policies towards Rwandans contradict her reputation of protecting refugees. There is evidence of discrimination against Rwandan refugees". ${ }^{152}$ There are similar claims of discrimination and harassment by other sources. ${ }^{153}$

\subsection{Internal Sources}

\subsubsection{Domestic Violence}

Refugee women who fled violence in their countries of origin have experienced violence in Nakivale and Oruchinga settlements. This has also affected Rwandan refugee women. Domestic violence had worsened due to the ban on cultivation and reduction in food rations. Rwandan refugee women said that their husbands were more violent and abusive because of redundancy and drinking alcohol. One refugee woman said: "I have faced domestic violence. My husband beats me almost every day. He comes home in the night drunk and starts beating me. Our children have run away from our house for fear of being beaten and harassed. My husband used not to drink two years ago. He is now very disgruntled and abuses me all the time". ${ }^{154} \mathrm{~A}$ refugee woman noted: "Life is very hard

\footnotetext{
${ }^{143}$ Focus Group Discussion, Rubondo zone, Nakivale settlement on $12^{\text {th }}$ July 2016.

${ }^{144}$ Focus Group Discussion, Juru zone, Nakivale settlement on $30^{\text {th }}$ July 2016.

${ }^{145}$ Interview with an official of International Refugee Rights Initiative, Kampala on $23^{\text {rd }}$ August 2016.

146 This is a period when Uganda and Rwanda fought against each other in Kisangani, Democratic Republic of Congo. There were also accusations that the two neighbors were supporting each other's rebels and enemies. It took the mediation of UK Prime Minister, Tony Blair and other regional initiatives for the two countries to mend relations.

147 Barbara Harrell Bond, "Cessation Clause Uganda Style", op.cit.

148 Focus Group Discussion, Oruchinga settlement on $29^{\text {th }}$ August 2016.

149 Focus Group Discussion, Kabazana village, Nakivale settlement on $15^{\text {th }}$ June 2016.

${ }^{150}$ Interview with a refugee woman, Kigali village, Nakivale on $28^{\text {th }}$ June 2010.

${ }^{151}$ Focus Group Discussion, Juru zone, Nakivale Settlement on $30^{\text {th }}$ June 2010; Focus Group Discussion, Sangano Base Camp, Nakivale settlement on $10^{\text {th }}$ June 2016 .

${ }^{152}$ Interview with an official of Refugee Law Project, Kampala on $1^{\text {st }}$ September 2016.

${ }^{153}$ See International Refugee Rights Initiative, Refugee Law Project \& Social Science Research Council, “A Dangerous Impasse”, op.cit; Amnesty International, "Memorandum to the Government of Uganda", op.cit.

${ }^{154}$ Interview with a refugee woman, Juru trading centre, Nakivale Settlement on $1^{\text {st }}$ July 2010.
} 
these days. My husband spends the whole day at home. In the past we would both go to the gardens to work. But things have changed since the government told us not to cultivate. My husband's behavior has changed and he quarrels and beats me without any reason". ${ }^{155}$

A humanitarian official shared the same view: "Domestic violence is on the increase among Rwandan refugees. We get more cases these days. We attribute this to the ban on cultivation. The majority depend on cultivation as the main source of livelihood. With the ban on cultivation, the majority have resorted to drinking and other antisocial behavior". ${ }^{156}$ The Uganda Penal Code Act Cap.106 does not specifically provide that domestic violence is an offence. ${ }^{157}$ The absence of a specific law protecting women against domestic violence, fear, as well as being ostracized by the society, traditional beliefs and attitudes made refugee women more vulnerable to domestic violence. In this case, domestic violence includes a range of sexual, psychological and physical coercive acts against adult and adolescent women by a current or former intimate partner, without their consent.

\subsubsection{Sexual Abuse and Violence}

Another notable factor that curtailed the security of refugees was sexual abuse and violence. Refugees were living with threats of rape and defilement on a daily basis. Although measures had been taken to address sexual abuse and violence by a number of actors like Medical Teams International (MTI) and Germany Agency for Technical Cooperation (GTZ) $)^{158}$, it was common to hear of girls and women being defiled and raped. These cases were common at night and in isolated areas in Nakivale and Oruchinga settlements. It was also possible that some of the cases of sexual abuse and violence go unreported as refugee women and girls fear being laughed at and want to avoid the shame. All the respondents reported rape cases in the past when women ventured out into the bush to collect firewood. ${ }^{159}$

However, it was noted that women no longer went out for firewood. NGOs were distributing firewood in the settlement. ${ }^{160}$ Women used to be attacked as they went to the nearby Lake Nakivale to fetch water. However, the number of people going to fetch water at the lake has greatly reduced since water was being pumped to the settlement. ${ }^{161}$ Complaints of poor flow of water at the taps were registered. One refugee woman noted: "Rape cases used to be rampant when all of us used to go to the lake to fetch water. These days rape cases have reduced since there are few people going to the lake". ${ }^{162}$ Another refugee argued: "We have cases of rape and defilement in Nakivale which have affected our daughters and wives. These days UNHCR and NGOs have intensified the fight against sexual violence through sensitization and assistance to the victims. But they cannot completely stop the bad practice". ${ }^{163}$

Humanitarian officials concurred that there was a challenge of sexual violence. One respondent noted: "Obviously we do not receive all the cases of sexual violence. Some cases go unreported. Victims often fear to report for fear of public shame and losing their partners. They decide to keep quiet and suffer in silence". ${ }^{64}$ A medical doctor agreed: "Although professionally I am not allowed to comment on my patients' cases, sexual violence cases are common here in Nakivale. Much as NGOs have intervened to fight this problem, we still receive cases in the health centres". ${ }^{165}$ Similar findings were observed in the Kenyan refugee camps of Dadaab and Kakuma. ${ }^{166}$

\subsubsection{Local Brews}

Local brews were another driving factor of insecurity. Most respondents claimed that living in a refugee settlement

\footnotetext{
155 Interview with a refugee woman, Sangano Base Camp, Nakivale Settlement on $21^{\text {st }}$ June 2016.

${ }^{156}$ Interview with a Community Services Coordinator, GTZ, Nakivale on $6^{\text {th }}$ July 2010; Interview with Social Worker, American Refugee Committee, Nakivale settlement on $1^{\text {st }}$ August 2016.

157 The presumption that a spouse consents to sex with her partner throughout the marriage relationship means that the act of marital rape is legally impossible and cannot amount to domestic violence.

158 This was replaced by German Development Agency (GIZ).

159 Focus Group Discussion, Oruchinga settlement on $29^{\text {th }}$ August 2016.

160 Ibid.

${ }^{161}$ Focus Group Discussion, Kabazana village, Nakivale settlement on $15^{\text {th }}$ June 2016.

${ }^{162}$ Interview with a refugee woman, Juru zone, Nakivale Settlement on $3^{\text {rd }}$ July 2010.

${ }^{163}$ Focus Group Discussion, Sangano Base Camp, Nakivale Settlement on 24 June 2010.

${ }^{164}$ Interview with the Deputy Legal Officer, GTZ, Nakivale Settlement on $5^{\text {th }}$ July 2010.

${ }^{165}$ Interview with a Medical Doctor, Nakivale Health Centre, Nakivale Settlement on 4th July 2016.

166 See Jeff Crisp, "Forms and Sources of Violence in Kenya's Refugee Camps", op.cit 55-56; Halperin, Liv (2003), The Physical Security of Refugees in Kenyan Camps, Legal and Human Rights Implications, MA Thesis, Unpublished, April, available at http:fletcher.tufts.edu. (accessed on 26 September 2013); Odhiambo, Paul (2004), The State and Refugee Security: A Case of Kakuma Refugee Camp in North Western Kenya, M.A Dissertation, Unpublished, Kampala, Makerere University.
} 
for a long period of time was a rather frustrating experience. Some people started drinking alcohol for a variety of reasons: some said that they missed their homes and families, they had little to do in the settlement to spend their time, and they thought drinking was fun, or they wanted to avoid thinking about their problems. Refugees said: "Drinking alcohol helps us to forget about our problems. We are able to mix freely with our friends and pass time. Life in the settlement is boring. Drinking alcohol helps us to cope with boredom". ${ }^{167}$ Rwandan refugees resorted to drinking because of the ban on cultivation which left the majority without work that would keep them busy. In Rubondo zone, the research team saw a good number of Rwandan refugees drinking alcohol as early as 10 in the morning. This kind of life style feeds into a cycle of poverty and depression for families which leads to more drinking. Above all such drinking culminated into domestic violence, fighting and other crimes.

A humanitarian official noted: "drinking alcohol is common here in the settlement. It is one way of living with problems and stress. However, it tends to promote more problems and stress. Those who drink end up fighting, being wounded or divorcing. In my view drinking alcohol by refugees creates more problems for them". 168

\subsubsection{Idleness and Redundancy}

As already mentioned, an idle and redundant refugee population increases the risks of crimes and other violent behavior. People focus their energies on doing things that may not be productive in the long run. One respondent commented: "Redundancy is one of the causes of crimes here in Nakivale. Redundancy leads men into drinking and other criminal tendencies. There is need to empower refugees to start income generating activities as a strategy for ensuring security in camps". ${ }^{169}$ For example in Gisura village, Rubondo zone, a FGD was interrupted by refugee men who started fighting in the nearby small local bar. It became so rowdy and serious that some of the participants had to excuse themselves to quell the fighting. A similar finding is reported by Crisp who argues that the monotony of refugee life resulted in occasional outbreaks of violence in Kakuma and Dadaab. ${ }^{170}$

\subsubsection{Drug Abuse}

The researcher discovered that there were high rates of drug abuse among refugees in Nakivale settlement. It was also noted that Somali refugees were selling drugs around the settlement including Opium and Mira which in turn precipitated fighting and murder. ${ }^{171}$ For example, in 2008 a Rwandan man smoked opium, ran amok and killed a fellow Rwandan refugee by cutting him to pieces using a machete. This refugee man is at the moment serving a life imprisonment sentence in Kyamugorani prison in Mbarara. ${ }^{172}$

One NGO official argued: "Refugees engage in drugs as a coping strategy to their problems. The most common drugs here are marijuana and mirungi. These drugs make refugees commit crimes. We are currently having discussions among the implementing partners of UNHCR on the strategies to curb the problem of drug abuse". ${ }^{173}$

\subsubsection{Extreme Poverty}

Extreme poverty among the refugees was found to be one of the causes of insecurity. With a ban on cultivation which used to be the main source of livelihood, the majority of refugees found it difficult to have sustainable incomes and support themselves. One of the refugees had this to stay: "Life has become very difficult with the denial of land and a chance to cultivate. The majority of us are cultivators and we used to sell our crop harvests mainly maize and beans and get money. Rwandans are hardworking people. Lorries used to come from as far as Kampala, Eastern Uganda and Kenya to buy our crops. Now that we have been stopped from cultivating, the amount of harvest has drastically diminished here in Nakivale. The other refugee nationalities are not as hard working as us Rwandans". ${ }^{174}$

This view was supported by humanitarian officials and local Ugandans who noted that crop harvests had reduced with a ban on cultivation targeting Rwandan refugees. A local Ugandan man noted: "Nakivale has always been a source of maize and beans. However, this is slowly changing and the area no longer produces much harvest. We

\footnotetext{
${ }^{167}$ Focus Group Discussion, Rubondo zone, Nakivale Settlement on $8^{\text {th }}$ July 2010.

${ }^{168}$ Interview with a Social Worker, African Humanitarian Action, Nakivale Settlement on $2^{\text {nd }}$ July 2010.

169 Interview with a Refugee Livelihoods Coordinator, GTZ, Nakivale Settlement on $6^{\text {th }}$ July 2010.

170 Jeff Crisp, "Forms and Sources of Violence", op.cit: 55.

${ }^{171}$ Focus Group Discussion, Sangano Base Camp, Nakivale Settlement on $10^{\text {th }}$ June 2016.

${ }^{172}$ Interview with a male refugee leader, Kigali village, Nakivale settlement on $27^{\text {th }}$ June 2016.

173 Interview with a Protection Officer, GTZ, Nakivale Settlement on $1^{\text {st } J u l y ~} 2010$.

${ }^{174}$ Focus Group Discussion, Sangano Base Camp, Nakivale settlement on $24^{\text {th }}$ June 2010; Focus Group Discussion, Sangano Base Camp, Nakivale settlement on $10^{\text {th }}$ June 2016.
} 
attribute this to the ban on cultivation for Rwandan refugees since they used to be the leading farmers". ${ }^{175}$

Because of loss of income, refugees resorted to illegal means of survival like theft, prostitution and other criminal activities. A police officer attached to Juru police post noted that "the ban on cultivation for Rwandan refugees has led to an increase in crimes here in Nakivale. We have more cases of this group being caught as thieves and drunkards. For example, recently a Rwandan refugee stole a gun from this police post and we don't know where the gun is". ${ }^{176}$ After a few weeks the stolen gun was found in Bushenyi, roughly 100 Kilometers from Nakivale settlement. ${ }^{177}$ The study found a strong connection between the ban on cultivation, poverty and an increase in crimes in the settlements.

\subsubsection{Witchcraft}

The practice of witchcraft is widespread throughout Uganda's refugee community and beyond. A number of respondents cited instances of witchcraft as the main threat to their security. Witchcraft was mainly high due to the presence of people from various ethnicities and the consequential wrangles over limited resources. It was revealed that Congolese refugees were the most feared group as regards witchcraft. One of the refugees noted: "We fear Congolese witchcraft. They threaten us with their witchcraft and we keep quiet. Since they took our land they have used witchcraft to silence anyone who wants to claim land. There are people who had land wrangles with Congolese and have died under mysterious circumstances. We suspect that they could have died due to witchcraft". ${ }^{178}$

The views on witchcraft were also raised by the local hosts. A Ugandan woman agreed with this view: "Congolese practice witchcraft. People in this area fear them. They threaten us that they will kill us with their Congolese gods. When you report to the police they tell us to prove witchcraft. But how do you prove witchcraft? It is not easy". ${ }^{179}$ While it is difficult to prove these claims, there were many stories and testimonies of witchcraft among the refugees and host communities.

\section{Effects of Insecurity on the Rwandan Refugees}

Rwandan refugees have been affected by insecurity in a number of ways. They observed that the effects are at individual, family and community levels. The refugees pointed out that they were living in fear of abduction, arrest and murder from the Rwandan agents.

Secondly, the refugees had the fear of being forced to return to Rwanda as happened on $14^{\text {th }}$ July 2010 . As already mentioned the refugees were now sleeping in the bush and changing residences for fear of being rounded up and put on trucks. One refugee woman observed: "We live in constant fear of being forced to return" ${ }^{180}$ A refugee man said: "We fear for our lives. We know Kagame agents will either kidnap or murder us. There are recent examples to prove my point. If Kagame's men can target Kayumba in South Africa, what about us? We are in Kagame's compound". ${ }^{181}$ This was understandable given the way forced return of Rwandan asylum seekers and refugees was carried out in Uganda, Tanzania, Burundi and DRC. ${ }^{182}$

Another effect of insecurity was the loss of lives. The refugees claimed that some of their colleagues had committed suicide in the nearby Lake Nakivale for fear of being forced to return. Other refugees lost their lives due to murder, fighting and robbery. As already mentioned, a Rwandan refugee was killed by nationals in Ngarama sub-county in

\footnotetext{
175 Interview with a Ugandan man, Kahirimbi trading centre, Nakivale Settlement on $16^{\text {th }}$ July 2010.

${ }^{176}$ Interview with a Police man, Juru police post, Juru zone, Nakivale on $1^{\text {st }}$ July 2010.

177 Interview with a Police man, Juru zone, Nakivale on $30^{\text {th }}$ June 2016.

${ }^{178}$ Interview with a refugee woman, Kigali village, Nakivale on $28^{\text {th }}$ June 2016.

179 Interview with a Ugandan woman, Kibengo village, Ngarama Sub County on $17^{\text {th }}$ July 2010.

${ }^{180}$ Interview with a refugee woman, Juru Zone, Nakivale on 20th July 2016.

${ }^{181}$ Interview with a refugee man, Oruchinga settlement on $30^{\text {th }}$ August 2016; Interview with a refugee man, Oruchinga settlement on $26^{\text {th }}$ January 2018.

${ }^{182}$ See Whitaker Beth Elise (2003), "Changing Priorities in Refugee Protection: The Rwandan Repatriation from Tanzania" in Niklaus Steiner, Mark Gibney\& Gil Loesher (Eds), Problems of Protection: The UNHCR, Refugees and Human Rights, New York \& London, Routledge: 141154;Amnesty International (1997), Human Rights Overlooked in Mass Repatriation, $14^{\text {th }}$ January, available at http://www.essex.ac.uk/armedcon/story_id/Human\%20Rights\%20Overlooked\%20in\%20Mass\%20Repatriation.pdf $\quad$ [accessed on $12^{\text {th }}$ November 2012] ; Amnesty International (2004), Rwanda Protecting their rights: Rwandese refugees in the Great Lakes region, available at http://www.amnesty.org/en/library/asset/AFR47/016/2004/en/f22d9445-d556-11dd-bb24 1fb85fe8fa05/afr470162004en.pdf [accessed on $4^{\text {th }}$ April 2012] ; Human Rights First (2004), A Decade of Unrest: Unrecognized Rwandan Refugees in Uganda and the Future of Refugee Protection in the Great Lakes, available at: http://www.humanrightsfirst.org/wp-content/uploads/pdf/Decade-of-Unrest.pdf [accessed on 30th June 2013]
} 
$2010 . .^{183}$

Families broke down as a result of domestic violence, rape and other forms of sexual abuse and violence. One refugee man stated that "I have separated from my wife because of rape. I feel angry about it". ${ }^{184}$ Another respondent said: "I no longer stay with my husband because of abuse and violence. I stay with my two children. My husband threatens me. I have reported to our Refugee Welfare Council Chairperson for intervention". ${ }^{185}$

The majority of the respondents said that children dropped out of school for fear of forced return. One respondent said: "Look at my children, they are here. They are not at school because we know any time we are returning home. Studying is wastage of time". ${ }^{186}$ The refugees were also escaping from settlements to the districts of Isingiro, Kyenjojo and Mubende. This outward movement put them at a great risk of being robbed or harassed by the communities where they went. In addition, they had no access to humanitarian assistance thus putting their lives at risk. Other sources have reported the challenges faced by Rwandan refugees in accessing basic services such as health, education and protection. ${ }^{187}$

The refugees further talked of psychological torture and loss of hope. They indicated that they had lost hope in life and put their lives in the hands of God. One refugee woman lamented: "We are here and not sure of tomorrow. We live under fear and uncertainty. No one knows whether we shall be alive or dead. Only God knows what lies ahead". ${ }^{188}$

\section{Physical Security Protection Measures by the Refugees}

Physical security protection is the responsibility of the government supported by UNHCR and NGOs. However, the responsibility of security also rests on refugees themselves. According to refugee law, refugees have duties to the country in which they find themselves and are required to respect the laws, regulations and measures taken for the maintenance of public order. ${ }^{189}$ This section focuses on those measures undertaken by refugees in ensuring security. Uganda used a participatory approach to security in which refugees played a role.

One of these measures was community vigilance and cooperation on security matters. The OPM and Uganda police engaged the refugees in community policing by requiring refugees to be responsible for security in the settlement. Refugees were obliged to report any wrongdoers and unknown people to the police or Refugee Welfare Councils (RWCs). As one refugee leader noted, "ensuring security here in Nakivale is everybody's responsibility including that of the refugees. No one should sit back and wait for police to do everything when we the refugees can offer a hand like sharing intelligence information, reporting wrong characters and other security related information". ${ }^{190}$ This approach is also being used in Kenyan camps specifically in Kakuma and Dadaab. Crisp refers to it as "community organization", based on the principle of community self-management. It is designed to empower the refugees to boost their involvement in camp life. ${ }^{191}$ The Uganda police uses a similar approach of community policing in maintaining security.

Another strategy was the use of Refugee Welfare Councils (RWCs) in monitoring security in the settlement. The RWCs are the same as Local Councils (LCs) ${ }^{192}$ in the Ugandan decentralization system. A refugee leader noted: "RWC leaders are elected by the refugees every year. RWCs serve as civic administration for the refugees". ${ }^{193}$ "They act as mediators in cases of conflicts between refugees. They also collaborate with the Office of the Prime

\footnotetext{
183 The researcher and his team were at the time doing data collection in Nakivale settlement and they heard about the murder of this Rwandan refugee in Ngarama sub-county neighboring Nakivale. The Settlement Commandant and the Legal Officer of GTZ, an implementing agency of UNHCR confirmed the murder of this Rwandan refugee man.

184 Interview with a refugee man, Kigali village, Nakivale on $29^{\text {th }}$ June 2010

185 Interview with a refugee woman, Sangano Base Camp, Nakivale Settlement on $23^{\text {rd }}$ June 2010.

${ }^{186}$ Interview with a refugee woman, Juru zone, Nakivale Settlement on $14^{\text {th }}$ July 2016.

187 Amnesty International, "Memorandum to the Government of Uganda" op.cit: 11-13.

${ }^{188}$ Interview with a refugee woman, Rubondo zone, Nakivale Settlement on $10^{\text {th }}$ July 2010.

189 See Article 2 of 1951 UN Convention; Article III (1) of 1969 OAU Convention; Section 35(a-f) of the Uganda 2006 Refugees Act.

${ }^{190}$ Interview with a refugee male leader, Juru zone, Nakivale settlement on $10^{\text {th }}$ July 2016.

191 Crisp Jeff "A State of Insecurity", op.cit

${ }^{192}$ Local Councils in Uganda are made up of a 9 persons' committee headed by a Chairperson. LCs start at LC1 at village level, LC 2 is parish, LC 3 is sub-county, LC 4 County and LC 5 is a District. The most active levels are LC1, LC3 and LC 5. For example, at LC 1, there is a Chairperson and Defence Secretary who are fully in charge of security issues in the village. The village also has Local Defence Units (LDUs) that ensure security at a local level. On top is Sub-County Internal Security Organization (ISO), District ISO, Regional ISO and National ISO under the President's office. For refugees, RWCs operate at RWC 1, RWC 2 and RWC 3 which is an equivalent of village, parish and subcounty respectively under the Ugandan decentralization system.

${ }^{193}$ Interview with a refugee male leader, Kigali village, Nakivale settlement on $18^{\text {th }}$ June 2016.
} 


\section{Minister". ${ }^{194}$}

The RWCs engage in security patrols in refugee villages and zones, resolving disputes and cooperating with police and OPM. The most influential members of RWC include the Chairperson and Defence Secretary. A refugee noted that: "We work with OPM and police in ensuring security. RWCs are the ears and eyes of OPM in the settlement. They hear and see what goes on in our villages and inform the OPM and police". ${ }^{195}$

This was confirmed by the settlement commandant who observed that RWCs were the watch dogs of OPM in matters of security. ${ }^{196} \mathrm{He}$ noted that without RWCs, it would be hard to ensure security for the hundreds of thousands of refugees. ${ }^{197}$

Finally, the refugees ensured security through the planting of Euphorbia tirucalli (locally known as "oruyenje") fences around their homes. These are trees that people use in land marks/demarcations and work as fences around people's homes. The researcher observed these fences around refugee homes. In most communities in Uganda, these fences are used in keeping animals in farms. These Euphorbia tirucalli are an equivalent of thorn fences used in refugee camps in Kenya and Tanzania.

\section{Conclusion}

This article has argued that much as Uganda has been praised worldwide as being friendly and hospitable to refugees, Rwandan refugees were faced with physical insecurity in violation of the country' international obligations. Based to a large extent on the views of Rwandan refugees, this paper has explored the dynamics of refugee physical (in) security in Nakivale and Oruchinga settlements. It was noted that Rwandan refugees are threatened by their country of origin, the host state and local settlement dynamics. Rwanda's threats include spying and abductions. A number of refugees have been abducted either from the settlements or other parts of Uganda. Rwandan has also influenced refugee policy such as forced repatriation, ban on cultivation and reduction of humanitarian assistance. Nakivale and Oruchinga are located approximately 70 and 52 kilometers respectively from the Rwandan border (Kagitumba/Mirama Hills) and are easily accessed by its security agents. Favored by the two countries' close relationship, Rwandan agents moved freely harassing refugees.

The paper has further noted that refugees were threatened by local settlement dynamics that included conflicts, the large and open nature of the settlement, the composition of refugee population, protests, armed robbery, theft and local politics. One can argue that refugees moved from one conflict to another. Rwandan Hutu-Tutsi conflicts were very alive in the settlements. The Hutu accused the Tutsi of spying on them on behalf of the Rwandan government. Land conflicts with Congolese refugees and local hosts were also a source of insecurity. Other sources included shortcomings and challenges of the host state, the small police force, ban on cultivation, forced repatriation, the two countries' close relationship and discriminatory tendencies.

A number of physical protection measures were adopted by the refugees in the settlement. Refugees were involved in the day to day management of security through RWCs and planting of Euphorbia tirucalli. These measures by the refugees were implemented alongside those of the government and the UNHCR. Despite the implementation of a number of protection measures, insecurity still prevails.

The insights in this article have methodological and policy implications. From a methodological perspective, more work needs to be done to identify and explore the differences between the official narrative of government, UNHCR and NGOs and the views of refugees who are affected by insecurity. Most times, the official narrative supports the view that refugees are secure and protected. All that is presented is how UNHCR, NGOs and government fulfill their obligations of protecting refugees. It might be argued that the findings in this article do not correspond with the widely accepted view that refugees are secure and protected in Uganda. Using a human security approach and exploring the views of refugees helps us to understand physical security and protection from their perspective and experiences. There is therefore need for further research on this issue.

Furthermore, this paper has focused on physical security of Rwandan refugees. The 1994 UNDP Human Development report raised other aspects of human security like economic, food, health, political, community and environmental security. It is important to do further research on the above aspects of human security in the context

\footnotetext{
${ }^{194}$ Natukunda Pheonah (2008), Women and Domestic Violence in Uganda: A Case Study of Refugee Women in Kyaka II Refugee Settlement in South Western Uganda, MA Dissertation, Unpublished, Harare, University of Zimbabwe: 17.

195 Interview with Refugee Welfare Council Defence Secretary, Sangano Base Camp, Nakivale Settlement on 30 $0^{\text {th }}$ June 2016; Interview with Chairperson, Refugee Welfare Council 1, Sangano Base Camp, Nakivale settlement on $26^{\text {th }}$ January 2018.

${ }^{196}$ Interview with Settlement Commandant, Nakivale Refugee Settlement on $25^{\text {th }}$ June 2010; Interview with Settlement Commandant, Nakivale settlement on $28^{\text {th }}$ January 2018.

${ }^{197}$ Ibid.
} 
of Rwandan refugees in Uganda.

From a policy perspective, the use of the human security concept and approach in security studies and international relations generally is increasingly becoming widespread in refugee protection, humanitarian intervention, responsibility to protect, development and security practice, peace building and conflict resolution. Human security is people centered. This means people (refugees) should be at the center of protection decisions and policies made by governments, UNHCR and NGOs. This would mean listening and consulting refugees in matters affecting their security. Refugees need not to be mere recipients but participants of their security and protection.

\section{References}

Ahimbisibwe, F. (2013). The Effect of Land Conflicts on the Livelihoods of Refugees: Implications for Refugee Protection in Uganda. Research Journal of Social Science and Management, 3(6), 19-28.

Ahimbisibwe, F. (2015). The Host State and Refugee Security in Uganda: The Case of Rwandan Refugees in Nakivale Settlement, Doctoral Dissertation, Unpublished, Mbarara, Mbarara University of Science and Technology.

Alupo, S. (2009). State Responsibility for the Rights of Refugees: A Critical Analysis on the Security of Refugees in Uganda, Master Thesis, Unpublished, Oslo, University of Oslo.

Amahoro People's Congress, Rwanda National Congress \& FDU-Inkingi. (2013). Open Letter to the President on the Treatment of Rwandan Asylum Seekers and Refugees Living in Uganda, $7^{\text {th }}$ November. Retrieved January 15, 2014, from http://www.fdu-rwanda.com/wp-content/uploads/2013/11/Letter-to-President-Museveni-onRwandan-refugees.pdf

Amnesty International. (1997). Human Rights Overlooked in Mass Repatriation, 14 ${ }^{\text {th }}$ January. Retrieved November 12, 2016, from http://www.essex.ac.uk/armedcon/story_id/Human\%20Rights\%20Overlooked\%20in\%20Mass\%20Repatriat ion.pdf

Amnesty International. (2004a). Rwanda: The Enduring Legacy of Genocide and War, $5^{\text {th }}$ April.

Amnesty International. (2004b). Rwanda Protecting their Rights: Rwandese Refugees in the Great Lakes Region. Retrieved April 4, 2012, from http://www.amnesty.org/en/library/asset/AFR47/016/2004/en/f22d9445-d55611dd-bb24 1fb85fe8fa05/afr470162004en.pdf

Amnesty International. (2011). Memorandum to the Government of Uganda about the Cessation of Refugee Protection for Rwandans. Index: AFR 59/021/2011, London, Amnesty International Publications, December.

Bagenda, E., Naggaga, A., \& Smith, E. (2003). Land Problems in Nakivale Settlement and the Implications for Refugee Protection in Uganda. Refugee Law Project Working Paper No. 8, May. Retrieved from http://www.refugeelawproject.org/working_papers/RLP.WP08.pdf

Baldwin, D. A. (1997). The Concept of Security. Review of International Studies, 23(1), 5-26. https://doi.org/10.1017/S0260210597000053

Brenda, B. S. (2011). States' Obligations to Protect Refugees Fleeing Libya: Backgrounder. March 1. Retrieved October 15, 2011, from http://www.humanrightsfirst.org/2011/03/01/states-obligations-to-protect-refugeesfleeing-libya-backgrounder/

Buzan, B. (1991). People, States and Fear: An Agenda for International Security Studies in the Post-Cold War Era (2nd ed.). New York: Harvester Wheatsheaf.

Crisp, J. (2000). A State of Insecurity: The Political Economy of Violence in Kenya's Refugee Camps. African Affairs, 99, 601-632. https://doi.org/10.1093/afraf/99.397.601

Crisp, J. (2000). Forms and Sources of Violence in Kenya's Refugee Camps. Refugee Survey Quarterly, 19(1), 5470. https://doi.org/10.1093/rsq/19.1.54

Fahamu Refugee Programme. (2011). Rwanda; Cessation of Refugee Status is Unwarranted-Memo of Fact and Law. Retrieved January 27, 2014, from http://www.refugeelegalaidinformation.org/sites/srlan/files/fileuploads/Memo\%20of $\% 20$ Fact $\% 20$ and $\% 20$ Law.pdf

Halperin, L. (2003). The Physical Security of Refugees in Kenyan Camps, Legal and Human rights Implications, MA Thesis, Unpublished. Retrieved September 26, 2013, from http:fletcher.tufts.edu

Harrell-Bond, B. (2011). Cessation Clause Uganda Style, Keynote Speech Delivered at the Northwestern 
University Conference on Human Rights, January 23, Working Paper 11-001, January.

Human Rights First. (2004). A Decade of Unrest: Unrecognized Rwandan Refugees in Uganda and the Future of Refugee Protection in the Great Lakes. Retrieved June 30, 2016, from http://www.humanrightsfirst.org/wpcontent/uploads/pdf/Decade-of-Unrest.pdf

Human Rights Watch. (2002). Hidden in Plain View: Refugees Living Without Protection in Nairobi and Kampala. New York: Human Rights Watch Publications.

International Refugee Rights Initiative, Refugee Law Project \& Social Science Research Council. (2010). A Dangerous Impasse: Rwandan Refugees in Uganda. Retrieved November 15, 2016, from http://refugeelawproject.org/others/10_06_28_A_Dangerous_Impasse,Rwandan_Refugees_in_Uganda.pdf

Krause, K., \& Michael, C. W. (Eds.). (1997). Critical Security Studies. Minneapolis: University of Minnesota Press.

Milner, J. (2000). Sharing the Security Burden: Towards the Convergence of Refugee Protection and State Security. Refugee Studies Centre Working Paper No. 4, University of Oxford, May.

Milner, J. (2009). Refugees, the State and the Politics of Asylum in Africa. Basingstoke: Palgrave Macmillan. https://doi.org/10.1057/9780230246799

Mujuni, R. (2014). Rwanda Denies Kidnapping Refugee in Uganda. New Vision. Retrieved April 17, 2014, from http://www.newvision.co.ug/news/654615-rwanda-denies-kidnapping-refugee-in-uganda.html

Musisi, F., \& Kasasira, R. (2014). Police Foil Kidnap of another Rwandan Refugee. Daily Monitor, Saturday April $12^{\text {th }}$. Retrieved April 12, 2014, from http://www.monitor.co.ug/News/National/Police-foil-kidnap-of-anotherRwandan-refugee/-/688334/2275862/-/15gcw6uz/-/index.html

Namanya, B. (2009). Urbanization and Security in Kampala City, Uganda. In G. Cordner et al. (Eds.), Urbanization, Policing and Security: Global Perspectives. London \& New York, CRC Press, Taylor \& Francis Group. https://doi.org/10.1201/9781420085587-c3

Natukunda, P. (2008). Women and Domestic Violence in Uganda: A Case Study of Refugee Women in Kyaka II Refugee Settlement in South Western Uganda, MA Dissertation, Unpublished, Harare, University of Zimbabwe.

OAU. (1969). Convention Governing the Specific Aspects of Refugee Problems In Africa, Assembly of Heads of African States and Governments, Addis Ababa, September 10, 1001 U.N.T.S. 45, entered into force June 20, 1974.

Odhiambo, P. (2004). The State and Refugee Security: A Case of Kakuma Refugee Camp in North Western Kenya, M.A Dissertation, Unpublished, Kampala, Makerere University.

ODI/HPG. (2004). Humanitarian Protection and Politics of Influence: A Study of Concepts and Practice in the Protection of Civilians. Discussion Paper, $25^{\text {th }}$ June.

Office of the President, Republic of Uganda, Report on the Investigative Findings on Nakivale and Oruchinga Refugee Settlements Carried out between 08/04/2005 to 10/04/2005, Ref. No. SPA/PA/18/07/02/05, dated $22 / 03 / 2005$, on file with the author.

Office of the Prime Minister \& UNHCR. (2020). Uganda Comprehensive Refugee Response Portal. Retrieved June 30, 2020, from http://ugandarefugees.org/en/country/uga/

OPM, UNHCR \& World Food Programme. (2010). The Joint Assessment Mission Final Report, March.

Paris, R. (2001). Human Security: Paradigm Shift or Hot Air? International Security, 26(2), 87-102. https://doi.org/10.1162/016228801753191141

Refugee Law Project. (2004). Land and Ethnicity in Nakivale Refugee Settlement: The Need to Resolve Competing Claims and Address Tensions. Retrieved December 1, 2016, from http://www.refugeelawproject.org/files/archive/2004/RLP.nakivale.land.pdf

Republic of South Africa. (1996). South African White Paper on Defence. Pretoria, Ministry of Defence.

Republic of Uganda. (2002). Ugandan White Paper on Defence. Kampala, Ministry of Defence.

Reyntjens, F. (2013). Political Governance in Post-Genocide Rwanda. New York, Cambridge University Press. https://doi.org/10.1017/CBO9781107338647

Rutinwa, B. (1999). The End of Asylum? The Changing Nature of Refugee Policies in Africa. New Issues in Refugee Research, Working Paper No. 5, Geneva, UNHCR, May. 
Straus, S., \& Waldorf, L. (Eds.). (2011). Remaking Rwanda: State Building and Human Rights After Mass Violence. Madison \& London, University of Wisconsin Press.

The Refugees Act 2006, Uganda, 24 ${ }^{\text {th }}$ May 2006.

Tumushabe, A. (2011a). Nakivale Refugees and Police Clash. Daily Monitor, Friday, $7^{\text {th }}$ January.

Tumushabe, A. (2011b). Refugees Harass us- Isingiro Locals. Daily Monitor, Monday, $31^{\text {st }}$ October.

UN. (1951). Convention Relating to the Status of Refugees, adopted on July 28th by the United Nations Conference of Plenipotentiaries on the Status of Refugees and Stateless Persons convened under General Assembly resolution 429(V) of December 14, 1950 entered into force April 22, 1954.

UNDP. (1994). Human Development Report. New York \& Oxford, Oxford University Press. Retrieved May 13, 2016, from http://hdr.undp.org/sites/default/files/reports/255/hdr_1994_en_complete_nostats.pdf

UNHCR. (1999). Handbook for Emergencies, Geneva, UNHCR.

UNHCR. (2006). State of the World's Refugees: Human Displacement in the New Millennium. Oxford, Oxford University Press.

UNHCR. (2020). Global Trends: Forced Displacement in 2019. Geneva, UNHCR: 2. Retrieved June 19, 2020, from http://www.unhcr.org/globaltrends2019/

United Nations. (1967). General Assembly, Protocol Relating to the Status of Refugees. 31st January, United Nations, Treaty Series, Vol. 606, p.267. Retrieved from http://www.refworld.org/docid/3ae6b3ae4.html

Whitaker, B. E. (2003). Changing Priorities in Refugee Protection: The Rwandan Repatriation from Tanzania. In N. Steiner, M. Gibney, \& G. Loesher (Eds.), Problems of Protection: The UNHCR, Refugees and Human Rights (pp. 141-154). New York \& London, Routledge.

\section{Copyrights}

Copyright for this article is retained by the author(s), with first publication rights granted to the journal.

This is an open-access article distributed under the terms and conditions of the Creative Commons Attribution license (http://creativecommons.org/licenses/by/4.0/). 